J. Linguistics 58 (2022), 609-648. C The Author(s), 2020. Published by Cambridge University Press. This is an Open Access article, distributed under the terms of the Creative Commons AttributionNonCommercial-NoDerivatives licence (http://creativecommons.org/licenses/by-nc-nd/4.0/), which permits non-commercial re-use, distribution, and reproduction in any medium, provided the original work is unaltered and is properly cited. The written permission of Cambridge University Press must be obtained for commercial re-use or in order to create a derivative work.

doi: $10.1017 /$ S0022226720000419

\title{
Discontinuous noun phrases in Yucatec Maya ${ }^{1}$
}

\author{
STAVROS SKOPETEAS (1) \\ University of Göttingen \\ ELIS ABETH VERHOEVEN (1) \\ Humboldt University Berlin \\ GISBERT FANSELOW (1) \\ University of Potsdam
}

(Received 3 November 2017; revised 17 July 2020)

Languages differ in whether or not they allow discontinuous noun phrases. If they do, they further vary in the ways the nominal projections interact with the available syntactic operations. Yucatec Maya has two left-peripheral configurations that differ syntactically: a preverbal position for foci or $w h$-elements that is filled in by movement, and the possibility to adjoin topics at the highest clausal layer. These two structural options are reflected in different

[1] The data presented in this article were collected in five field trips in the period 2004-2019. We are particularly grateful to the four native speakers who contributed with their judgments to the results of this study, Amedee Colli Colli (Felipe Carrillo Puerto), Ernesto May Balam, Ramon May Cupul, and Fulgencio Ek Ek (Yaxley, Quintana Roo, Mexico). We received many insightful comments on various aspects of this study from Caroline Féry, Barbara Stiebels, Joanna Blaszcsak, and three anonymous Journal of Linguistics referees and its editor Hans van de Koot. We thank Maya Gálvez Wimmelmann for her assistance in the final editing of the manuscript. The research reported in this article was partially supported by the DFG-grant SK 252/4-1 for Stavros Skopeteas, by the DFG-grant VE 570/3-1 for Elisabeth Verhoeven, by the DFG-grant FA 255/5 to Gisbert Fanselow, Caroline Féry (and Martin Haspelmath for the project's first phase), as well as by the DFG grant SFB 632-D2 to Gisbert Fanselow, Caroline Féry and Manfred Krifka.

Glossing conventions adhere to the Leipzig Glossing Rules (Comrie, Haspelmath \& Bickel 2015). The following abbreviations are used in the article. $\mathrm{A}=$ person marker, set $\mathrm{A}$; $\mathrm{ACC}=$ accusative $; \mathrm{AN}=$ animate $; \mathrm{AOR}=$ aorist $; \mathrm{B}=$ person marker, set $\mathrm{B} ;$ CAUS $=$ causative; $\mathrm{CL} . \mathrm{AN}=$ class animate; $\mathrm{CL} . \mathrm{IN}=$ class inanimates; $\mathrm{CLT}=$ clitic; $\mathrm{CMPL}=$ completive; $\mathrm{CR}=$ complementizer; $\mathrm{D} 1=$ deictic clitic 1 (proximal); D2 = deictic clitic 2 (distal); D3 = deictic clitic 3 (neutral); DEF = definite; EXIST $=$ existential $; \mathrm{F}=$ feminine IN $=$ inanimate; INCMPL $=$ incompletive $;$ INDEF $=$ indefinite $; \mathrm{INTR}=$ intransitive; $\mathrm{IO}=$ indirect object; $\mathrm{IPFV}=$ imperfective, $\mathrm{LOC}=$ locative; $\mathrm{M}=$ masculine; $\mathrm{N}=$ neuter; $\mathrm{NEG}$ $=$ negation $; \mathrm{NOM}=$ nominative $; \mathrm{PART}=$ partitive $; \mathrm{PASS}=$ passive $; \mathrm{PFV}=$ perfective $; \mathrm{PL}=$ plural $; \mathrm{PROG}=$ progressive; PST $=$ past, $\mathrm{Q}=$ question particle; $\mathrm{RDP}=$ reduplication; $\mathrm{REL}=$ relationalizer; $\mathrm{SG}=$ singular; sUBJ $=$ subjunctive status; TERM $=$ terminative; $\mathrm{TRR}=$ transitivizer; $\varnothing=$ zero. 
ways of the formation of discontinuous patterns. Subextraction from nominal projections to the focus position yielding discontinuous NPs is possible, but subject to several restrictions. It observes conditions on extraction domains, and does not apply to the left branch of nominal structures. The topic position also appears to license discontinuity, typically involving a nonreferential nominal expression as the topic and quantifiers/adjectives that form an elliptical nominal projection within the clause proper. Such constructions can involve several morphological and syntactic mismatches between their parts that are excluded for continuous noun phrases, and they are not sensitive to syntactic island restrictions. Thus, in a strict sense, discontinuities involving the topic position are only apparent, because the construction involves two independent nominal projections that are semantically linked.

Keywords: discontinuous noun phrases, focus movement, left dislocation, possessor extraction, split topicalization

\section{INTRODUCTION}

The literature on discontinuous noun phrases often has an emphasis on the conditions that account for cross-linguistic variation. For example, Ross (1986) observed that left branches of noun phrases cannot be set off from the rest of the noun phrases in languages such as English, but he also noted (Ross 1986: 146) that the LEFT BRANCH CONDITION $^{2}$ is not operative in highly inflecting languages that allow for scrambling. Hale (1983) included discontinuity - along with free word order and null anaphora among the phenomena establishing the distinction between configurational and non-configurational languages. Subsequent research has shown that crosslinguistic variation in discontinuity demands a framework of higher granularity. For example, non-configurational languages such as Warlpiri and Mohawk do not display the same possibilities of discontinuity (see Baker 2001: 430) and certain types of split nominal structures may appear in configurational languages too, as already established for English in the early days of research on phrase structure.

The perspective of the present paper is a different one: it investigates the properties of discontinuous noun phrases within a single language - Yucatec Maya - as a function of the structural position occupied by the parts of the construction. Yucatec Maya is a V-initial language with two left-peripheral configurations, for topics and foci/wh-elements, respectively. In some examples, such as (1), the constituent in the topic or focus position could be a subconstituent of a nominal in the core clause.

(1) Ch'oom $_{\mathrm{i}}=\mathrm{e}^{\prime}$ mina'an u páajtalil $\mathrm{u}_{\mathrm{i}}$ k'aay jach uts... buzzard=D3 NEG.EXIST A.3 possibility A.3 song very nice 'It is not possible for the buzzard to sing very nice.'

(lit.: 'The possibility of the very nice song of the buzzard does not exist.')

[2] Left Branch Condition: 'No NP which is the leftmost constituent of a larger NP can be reordered out of this NP by a transformational rule.' (Ross 1986: 127) 


\section{(Academia de la Lengua y Cultura Mayas de Quintana Roo 2007: 11) ${ }^{3}$}

In (1), the possessor ch'oom 'buzzard' is realized in the topic position (identified by the enclitic $e^{\prime}$ ) and is related to the head-marked nominal head $u$ k'aay 'his song' that appears postverbally; the canonical order of (continuous) possessed noun phrases is head-initial, i.e. $u$ k'aay ch'oom 'the song of the buzzard'. This example belongs to a class of (apparently) discontinuous constructions that is termed SPLIT TOPICALIZATION and contains a topic that could be a subconstituent of the nominal projection within the clause proper. The main question of the present study is whether this is indeed an extracted subconstituent or not; in the latter case, discontinuity would only be apparent.

Apparent discontinuous noun phrases do not always result from an application of subextraction from a continuous nominal projection. In a descriptive sense, discontinuous structures are established whenever potential subconstituents of a nominal projection appear in linearly non-adjacent positions, but the derivational history of such constructions need not be uniform. Some discontinuous constructions have properties of $\overline{\mathrm{A}}$-movement - for example, they are sensitive to syntactic conditions on the extraction domain, such that subextraction is only allowed from governed syntactic projections (see Condition on Extraction Domain, Huang 1982: 505). ${ }^{4}$ Several models have been proposed for such cases: the most straightforward implementation is that a nominal subconstituent has undergone successive cyclic movement out of the DP structure, i.e. via the specifier position of the DP (Longobardi 1991 on Italian; Szabolcsi 1994: 181 for possessor extraction in Hungarian). Another possibility is that the split structure is formed within the clause proper by extraposing a nominal subconstituent to the right, such that the incomplete category left behind is fronted to a higher position by $\overline{\mathrm{A}}$-movement (Müller 1998).

Other discontinuous constructions, notably several instances of split topicalization, come with properties that are excluded in continuous noun phrases (e.g. multiple occurrences of nouns, or a number mismatch between the parts of the discontinuous constituents; see Fanselow 2013 for a detailed list). A simple explanation for these data is that their formation does not involve movement, rather, they just involve two separate nominal projections.

Still at least for some languages, constructions with properties that appear incompatible with a movement analysis nevertheless display some properties of $\bar{A}$-movement (e.g. sensitivity to island constraints, reconstruction effects; see Ott 2012 for a recent detailed account of the German facts), which has given rise to several syntactic proposals. A subextraction analysis can be maintained for such

[3] Full bibliographic information about the Maya text sources cited in this article will be found in the appendix rather than in the regular list of references.

[4] Constraint on Extraction Domain (CED): 'A phrase A may be extracted out of a domain B only if B is properly governed.' (Huang 1982: 505) 
constructions with mixed properties by, for example, timing morphology after syntax, which opens the possibility of morphological mismatches in number (see e.g. Riemsdijk 1989 for the idea of a 'regeneration' of noun phrase subconstituents to full maximal projections after extraction). An alternative view is that while the $\bar{A}$-movement properties of such mixed constructions result from a leftward movement, this movement does not originate inside a continuous noun phrase - both subconstituents of the construction are first merged independently of each other within the clause proper, either in different positions within the extended projection of the verb (Fanselow 1988) or as predicational structures (Ott 2012).

The present study will examine these options in the discontinuous constructions of Yucatec Maya. The elaborate left periphery of Yucatec Maya offers a promising testing ground for the generalizations about the derivational properties of these constructions. A crucial property of this language is that left-peripheral focus and $w h$-constructions are derived through movement, while topics are first merged in the left periphery; see Section 2 . The possibilities of discontinuity are dealt with in Section 3 for quantifiers and adjectives at the left branch of the nominal structure, in Section 4 for nominal heads, and in Section 5 for possessors and further types of DP/PP subconstituents. Section 3 presents the possible patterns of apparent discontinuity involving an adjoined nominal head at the topic position and a focused modifier in situ. We demonstrate that this construction confronts us with a structure in which two noun phrases syntactically independent of each other are semantically related to the same argument slot of the verb, so that, in a strict sense, no real discontinuity is present. In contrast to adjectives and quantifiers, nominal heads and DP subconstituents (possessors and partitives) can be subextracted from nominal structures by means of $\bar{A}$-movement (see Section 4 and 5) to the focus position. The conclusions of this study are summarized in Section 6.

Our data were provided by four native speakers in the municipalities of Yaxley and Felipe Carrillo Puerto, which are part of the zona maya of Quintana Roo, Mexico. They acquired Yucatec Maya as their first native language and actively use it in everyday life, while being all bilingual in Spanish. The initial data collection was based on a QUESTIONNAIRE ON DISCONTINUOUS NOUN PHRASES (created by the DFG-project Discontinuous Noun and Prepositional Phrases, University of Potsdam, headed by Gisbert Fanselow and Caroline Féry), which is a crosslinguistic elicitation tool encompassing elicitation tasks (target structures embedded in the expected licensing contexts) for different types of discontinuity. After lexicalizing the target utterances in Yucatec Maya, we discussed their wellformedness with native speakers in qualitative elicitation sessions. In most cases, we constructed contexts simulating a (monological or dialogical) discourse setting in Yucatec Maya, which are given in brackets whenever relevant for the discussion (translated into English for space reasons). These contexts are supposed to establish 
the appropriate discourse situation in which the syntactic structures under discussion are potentially licenced (see Matthewson 2004). We generally chose 'minimal contexts', such as a wh-question or a single sentence establishing the relevant referents (similar to the contexts for the elicitation of information-structural effects in Aissen 2020), so that speakers process the crucial contextual properties without constructing a richer communicative setting, with an incommensurable amount of shared knowledge. Whenever possible, we integrate examples from published texts or text collections to support the ecological validity of our observations. However, in the absence of available rich corpora for Yucatec Maya and given the granularity of our hypotheses, it would certainly not be feasible to replicate our findings through corpus data at this moment. Beyond the limitations of the available corpus resources, our main target is exactly to assess the intuitions of speakers about POSSIBLE STRUCTURES in their native language; the occurrence of these possibilities in language usage is determined by further factors, which are certainly relevant to understand - but are also partially independent from the aim to figure out the set of possible structures in a given language.

\section{Clausal structure}

The canonical word order in Yucatec Maya is VOS (Norman \& Campbell 1978: 144; Lehmann 1990: 44, 2002: 28; Bohnemeyer 1998; Skopeteas \& Verhoeven 2005, 2009a). ${ }^{5}$ Adverbs and PPs follow the subject, as illustrated for adjuncts in (2a) and complement PPs with intransitives and ditransitives in (2b, c).

(2) (a) $\mathrm{T}=\mathrm{u}$ jaan-t-aj oon peedróoj jo'olje'ak. $\mathrm{PFV}=$ A.3 eat-TRR-CMPL[B.3] avocado Pedro yesterday 'Pedro ate avocado yesterday.'

(b) J tu'ub maariáaj ti' peedróoj. PFV forget[B.3] Maria LOC Pedro 'Maria forgot Pedro.'

(c) $\mathrm{T}=\mathrm{u}$ ts'a'-aj waaj maariáaj ti' peedróoj. $\mathrm{PFV}=$ A.3 give-CMPL[в.3] tortilla Maria LOC Pedro 'Maria gave tortilla to Pedro.'

The lexical verb is preceded by an aspectual-modal auxiliary hosting a 'set A' marker, which bears phi-features valued by the external argument, i.e. the subject of transitive verbs or the subject of intransitive verbs in the incompletive status. ${ }^{6}$ The

[5] There is a long discussion about the analysis of the basic word order as VOS or SVO in Yucatec Maya, which does not affect the claims of the present study (see Skopeteas \& Verhoeven 2009a, Gutiérrez Bravo \& Monforte y Madera 2010 for summaries of the arguments for both analyses and further references).

[6] In Yucatec Maya, 'status markers' are verbal suffixes in agreement relation with the aspectual/ modal auxiliary. 
lexical verbs in (2a) and (2c) bear a status marker 'completive' which is selected by the auxiliary. The lexical verb bears a 'set B person' suffix (zero in the 3rd person) that cross-references the object of transitive verbs in (2a) and (2c) or the subject of intransitives in the completive/subjunctive status in (2b).

The order of PPs is flexible, as seen in (3), but the preferred option in (3a) corresponds to the expected linearization for ascending $\mathrm{V}$ projections (Janke \& Neeleman 2012: 157).

(3) (a) Peedróoj=e' táan u tsikbal yo'osal ch'íich'-o'ob yéetel maariáaj. Pedro=D3 PROG A.3 discuss for bird-PL with Maria 'Pedro speaks about birds with Maria.' (preferred)

(b) Peedróoj=e' táan u tsikbal yéetel maariáaj yo'osal ch'íich'-o’ob. Pedro=D3 PROG A.3 discuss with Maria for bird-PL 'Pedro speaks about birds with Maria.' (acceptable, not preferred)

String-adjacency between $\mathrm{V}$ and $\mathrm{O}$ is preferred, as seen in (4a); however, it is not mandatory, as illustrated with an intervening adverb in (4b).
(a) $\mathrm{T}=$ in jaant-aj jun-p'éel chiináaj jo'olje'ak. $\mathrm{PFV}=\mathrm{A} .1 \mathrm{SG}$ eat-CMPL[B.3] one-CL.IN orange yesterday 'I ate one orange yesterday.' (preferred)
(b) $\mathrm{T}=$ in jaant-aj jo'olje'ak jun-p'éel chiináaj. $\mathrm{PFV}=\mathrm{A} .1 \mathrm{SG}$ eat-CMPL[в.3] yesterday one-CL.IN orange 'I ate one orange yesterday.' (acceptable)

Furthermore, string-adjacency between $\mathrm{V}$ and $\mathrm{O}$ is violated by the VSO order that may occur in Yucatec Maya under particular configurations of animacy, definiteness and weight (see Skopeteas \& Verhoeven 2005, Bohnemeyer 2009 on Yucatec Maya; see Norman \& Campbell 1978: 144; Aissen 1992: 44; Coon 2016: 543 on other Mayan languages).

Verbs and direct objects precede subjects, oblique complements and adjuncts. This linearization is captured by raising the $\mathrm{V}$ and the $\mathrm{O}$ to functional projections above the thematic layer of the clause (vP). We assume that the lexical verb undergoes head-movement to the head position of an AspP, in which it checks its aspectual properties (status marker). The object constituent moves to a specifier position for objects; following minimalist assumptions, the object is hosted by a higher specifier position within the thematic layer of the clause (vP) (see Hornstein, Nunes \& Grohmann 2005: 168); see (5). We use the label T for the initial auxiliary, in order to facilitate the mapping to cross-linguistic assumptions about syntactic projections (see Henderson 2012: 8 on K'iche'); note, however, that the exact semantics of the auxiliaries in Yucatec Maya are precisely accounted for by the assumption of Asp(ect) and Mood heads instead (Gutiérrez Bravo 2017: 6). The structure in (5) follows the account of Clemens \& Coon (2018a) in deriving V-initial structures via head-movement. 


\section{(5) [TP $\left.\mathrm{T}\left[\mathrm{AspP} \mathrm{V}\left[{ }_{\mathrm{vP}} \mathrm{Obj}\left[\mathrm{v}^{\prime} \operatorname{Sbj}\left[\mathrm{vP}\left[\mathrm{vP} t_{\mathrm{V}}\left[t_{\mathrm{Obj}}\right]\right] \mathrm{XP}\right]\right]\right]\right]\right]$}

The subject in VOS is in situ in our analysis for Yucatec Maya, since postverbal subjects are not necessarily right side topics; see discussion of (14) below. This view is furthermore supported by the finding of the present study that subjects are not islands for subextraction (see Section 5.2).

Mayan languages have a discourse-configurational left periphery, which involves a 'focus position' used for constituents that are contrasted to further alternatives in the Common Ground, and a 'topic position' that hosts a constituent that is either in an aboutness relation with the comment or delimits a part of the propositional content of the utterance (see Krifka 2008 for detailed discussion; see Aissen 1992, 2017 for these configurations in Mayan languages). The focus position of Yucatec Maya is immediately preverbal and has quantificational properties, as seen in (6) (see Tonhauser 2003a; Gutiérrez Bravo 2015, 2017; Verhoeven \& Skopeteas 2015; AnderBois 2017 on Yucatec Maya).

(6) $\left[\mathrm{CP}\left[\mathrm{FP} \mathrm{XP}_{\mathrm{i}}\left[\mathrm{F}^{\prime} \ldots t_{\mathrm{i}} \ldots\right]\right]\right]$
A: $\{$ What is Pedro eating?
B: Oon $\mathrm{t}=\mathrm{u}$ jaan-t-aj peedróoj. avocado PFV=A.3 eat-TRR-CMPL[B.3] Pedro 'Pedro is eating AVOCADO.'

Narrow foci and $w h$-expressions in interrogatives, relative clauses and exclamatives are obligatorily left-adjacent to the predicate and mutually exclude each other. There is no empirical evidence for establishing a syntactic difference between these categories; there are no word order differences between focus and relative whexpressions that could support an analysis of these $w h$-expressions as specifiers of a higher functional projection within the CP layer. Hence, we assume that these elements land in the same position, the specifier of a functional projection, Spec,FP, in which either $w h$ - or focus features are valued. Elements in the Spec,FP must correspond to a clausal constituent and cannot co-occur with any (pronominal or lexical) element in their position in situ (corresponding to the IP projection in Aissen 1992; see Verhoeven \& Skopeteas 2015 on further syntactic properties of this projection in Yucatec Maya).

If the preverbal focus/wh-constituent is a subject of a transitive verb, an extrafocal inflection of the verb appears, the so-called 'agent-focus' construction, which is characteristic for Mayan languages (Bricker 1979; Lehmann 1990, 2002: 29; Bohnemeyer 1998: 190f.; Tonhauser 2003a; Stiebels 2006; Norcliffe 2009b; Gutiérrez Bravo 2015: 51; Verhoeven \& Skopeteas 2015). The properties of this construction in Yucatec Maya are (i) the drop of the aspectual auxiliary and the set A marker, and (ii) a special morphological form of the verb in the perfective aspect; compare (7) with (6). 
(7) A: $\{$ Who ate an avocado?\}

$\begin{array}{lll}\text { B: Peedróoj jaan-t } & \text { oon. } \\ \text { Pedro eat-TRR[SUBJ][B.3] avocado }\end{array}$

'PEDRO ate (an) avocado.'

This construction (optionally) appears only with subjects of transitive verbs (not with subjects of unergatives). The agent focus construction in Yucatec Maya differs from further Mayan languages in that the patient is not an oblique phrase (Stiebels 2006: 553-554; Norcliffe 2009b; Coon, Pedro \& Preminger 2014: 192).

Frame setters and topics ${ }^{7}$ may be adjoined to the left of the CP; see (8).

(8) $\left[\mathrm{CP} \mathrm{XP}_{\mathrm{j}}\left[\mathrm{CP}\left[\mathrm{FP} \ldots\left(\mathrm{pro}_{\mathrm{j}}\right) \ldots\right]\right]\right]$

A: $\{$ What happened with the avocados?

$B$ : Oon=e' t=u jaan-t-aj peedróoj. avocado $=\mathrm{D} 3 \quad \mathrm{PFV}=\mathrm{A} .3$ eat-TRR-CMPL[B3] Pedro

'As for avocados, Pedro ate (one/some).'

Left-adjoined phrases are clearly different from focus phrases: (i) the former MUST and the latter CANNOT be enclosed by an enclitic (see further details about these enclitics in Section 3.1), (ii) the former DO NOT and the latter Do trigger the agentfocus form of the verb; compare (8) with (7). Left-adjoined elements always precede foci and may be used recursively, giving rise to sequences of topics, while the position for foci/wh-/heads of relatives is unique. Subject/non-subject topic phrases can co-occur with a co-referent free pronoun within the FP (Skopeteas \& Verhoeven 2009b, Verhoeven \& Skopeteas 2015). Oblique arguments (which are not co-indexed with a cross-reference marker) must be resumed; see (9).

(9) Le nojoch máak=o', k=u y-a'al-a'al *(ti'=e') Tarzán? DEF big $\quad \operatorname{man}=\mathrm{D} 2 \quad$ IPFV=A.3 $\varnothing$-say-PASS.INCMPL LOC[B3]=D3 Tarzan 'As for the big man, is he called Tarzan?'

(lit.: 'is it said to him Tarzan')

(Monforte, Dzul \& Gutiérrez Bravo 2010: 55)

Topics are left-adjoined to the $\mathrm{CP}$ while foci are extracted from the clause proper by movement. ${ }^{8}$ This asymmetry is reflected in the reconstruction of binding relations with focus extraction (in contrast to topics). Yucatec Mayan subjects backwards bind into objects (Bohnemeyer 2009), see (10), which is expected if subjects c-command the trace of the object as in (5).

[7] Topics are related to their complement by an aboutness relation, while frame setters restrict a part of the propositional content of the utterance in several ways (see Krifka 2008: 268-269 for a detailed discussion).

[8] Further evidence comes from syntactic islands: focus fronting but not topicalization is sensitive to island constraints (Norcliffe 2009a: 82). 

$\mathrm{K}=\mathrm{u} \quad \mathrm{kol}-\mathrm{ik}$
$\mathrm{u}_{\mathrm{i} / \mathrm{j}} \mathrm{kool}$
káadaj jun-túul kolnáal ${ }_{j}$. IPFV=A.3 cut-INCMPL[B3] A.3 cornfield every one-CL.AN farmer 'Every farmer clears his cornfield.'

The binding possibilities do not change for objects in the pre-predicate position, which is evidence that this position is linked to the trace in situ by an $\bar{A}$-chain; see (11).

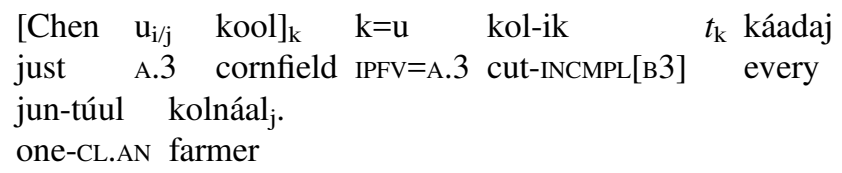

'It is just his cornfield that every farmer clears.'

However, these binding possibilities do not hold for adjoined topics. The possessor of the object constituent cannot be bound by a quantified subject in the topic position, as in (12), which indicates that this patient constituent is not linked to a trace in situ bound by the c-commanding subject. ${ }^{9}$

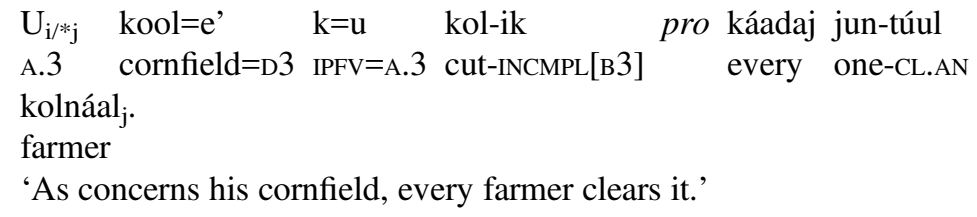

'As concerns his cornfield, every farmer clears it.'

Aissen (1992: 47) argues that two classes of left-peripheral topics appear in various Mayan languages: external topics that are base-generated in the left periphery and internal topics that originate in the thematic layer of the clause and move to the left periphery. Arguments for internal topics in Yucatec Maya are presented in Gutiérrez-Bravo \& Monforte y Madera (2008) and Gutiérrez Bravo (2011). The data reported in these studies differ from the variety of Yucatec Maya examined in this article, which is the Maya spoken in the Zona Maya of Quintana Roo: in our data, left-peripheral non-focal constituents (subjects or non-subjects) without topic markers are rejected. Hence, we assume that topic phrases are first merged in the left periphery, which accounts for the contrast between (11) and (12), the resumption of argument topics and the insensitivity of topic phrases to island conditions.

Right side topics also appear in Yucatec Maya and can be easily diagnosed by the behavior of right edge clitics. Such clitics are licensed by a definite article and

[9] It is crucial that the binding asymmetries are tested with quantified subjects; a version of (12) with a definite subject (e.g. le kolnáal=o' 'the farmer=D2') can be co-indexed with the left-adjoined object in a context in which the subject is the discourse topic (accidental co-reference). 
appear at the right edge of a CP boundary: they follow external topics but precede non-restrictive relative clauses and right-dislocated material (Skopeteas 2010). A crucial question for the analysis of VOS orders is whether postverbal subjects are right dislocated (Clemens \& Coon 2018a). In Yucatec Maya, clitics licensed by postverbal subject DPs appear at the right edge of the clause (and not at the right edge of the DP), as illustrated in (13), in which the enclitic $=o$ ' is licensed by the definite determiner of the subject, but follows the temporal adverb.
(13) J taal
le j-k'iin jo'olje' $a k=0$ '.
PFV come-INCMPL[в.3] DEF M-priest yesterday $=\mathrm{D} 2$
'The priest came yesterday.'

If the clause contains more than one DP, a single clitic appears at the CP boundary by haplology; this applies to the VOS order if the subject is not right dislocated, as in (14).
$\mathrm{K}=\mathrm{u} \quad \mathrm{x}$ ímbat-ik le j-meen le j-k'iin=o'.
$\mathrm{IPFV}=\mathrm{A} .3$ visit-INCMPL[B.3] DEF M-shaman DEF M-priest=D2
'The priest visits the shaman.'

If the enclitic is not final within the postverbal domain, the material following the enclitic is right dislocated. For instance, this is possible in the VOS order if the subject is background information, as in (15).

(15) A: \{Do you know whom the priest visits today?\}
$\mathrm{B}: \mathrm{K}=\mathrm{u}$ xíimbat-ik le j-meen $=0$ ' le j-k'iin=o'. $\mathrm{IPFV}=\mathrm{A} .3$ visit-INCMPL[B.3] DEF $\mathrm{M}$-shaman=D2 DEF $\mathrm{M}$-priest=D2 ' $\mathrm{He}_{\mathrm{i}}$ visits the shaman, the priest $\mathrm{i}_{\mathrm{i}}$.'

In sum, the clause structure of Yucatec Maya contains an articulated left periphery with configurations for foci and topics that can be identified by the enclitics and in case of preverbal transitive agents - by the verb morphology. The binding properties of foci provide evidence that the focused phrase binds a trace in the postverbal domain, while this evidence does not apply to topics. These properties motivate the following two predictions for discontinuous noun phrases:

\section{(16) Predictions}

(a) Syntactic entities in the FOCUS POSITION are related by a movement chain to a gap in situ. Noun phrase subconstituents in this position are expected to be related with a movement chain to a gap in the clause proper.

(b) Syntactic entities in the TOPIC POSITION are first merged within the higher clausal layer. Apparent noun phrase subconstituents in the topic position are expected to be independent nominal projections that are first merged there. 


\section{Quantifiers and adjectives}

This section examines the properties of 'split topicalization' in Yucatec Maya, i.e. constructions with a quantifier or adjective in the core clause and a head noun in the topic position. An examination of the syntactic properties of these constructions reveals that discontinuity is only apparent, i.e. that these constructions involve two separate nominal projections that are semantically related.

\subsection{Preliminaries}

The prenominal domain is strictly ordered: $\mathrm{D}>\mathrm{Q}>\mathrm{A}>\mathrm{N}$. There are no deviations from this order; for example, it is not possible for adjectives to scramble over the quantifiers or for adjectives/quantifiers to appear before the definite article (see Armstrong 2017: 158-159). We assume that this order directly reflects distinct layers of nominal projections; see (17).

$$
\text { [DP D [QP Q [aP A [nP]]]] }
$$

Definite phrases are introduced by the definite article le 'DEF'. This determiner obligatorily triggers a deictic enclitic, encoding a relation to the deictic center $(a$ ' 'D1' for proximal location to the deictic center; $o$ ' 'D2' for distal location to the deictic center; $e$ ' 'D3' for unspecified deictic properties). The use of the determiner le (originally a demonstrative) is certainly a recent development in Yucatec Maya. For instance, in the texts of Chilam Balam of Tizimin, which was composed (partly with earlier texts) in the first half of the nineteenth century, the definite article is virtually inexistent (see Edmonson 1982). In the contemporary language, this marker shows the range of uses that we expect for a definite article, i.e. it is anaphorically used with antecedents that are uniquely identified in the Common Ground and it also appears with generic interpretation (Vázquez-Rojas Maldonado et al. 2018: 223-235). The head of the QP is occupied by numerals, e.g. óox'three-', or quantifiers, e.g. ya'ab 'many', which follow the determiner and precede adjectives; compare (18a) and (18b).
(a) $\mathrm{T}=$ in $\mathrm{w}$-il-aj le óox-p'éel mejen naj-o'ob=o'. $\mathrm{PFV}=\mathrm{A} .1 \mathrm{SG} \varnothing$-See-CMPL[B.3] DEF three-CL.IN small house-PL=D2 'I saw the three small houses.'
(b) $* \mathrm{~T}=$ in $\mathrm{w}$-il-aj le mejen óox-p'éel naj-o'ob=o'. $\mathrm{PFV}=\mathrm{A} .1 \mathrm{sg} \quad \varnothing$-see-CMPL[в.3] DEF small three-CL.IN house-PL=D2 Intended: 'I saw the three small houses.'

The elements occurring as heads of APs are restricted in Mayan languages (Coon 2016): there is only a limited number of root adjectives and in some Mayan languages adjectives strictly select an NP, which disallows recursive embedding of APs, i.e. they only allow for a single prenominal adjective (Brown 1979: 105 on 
Poqomchi'; Dayley 1985: 195 on Tz'utujil; England 2004: 134 on Mam). In Yucatec Maya, only a few root adjectives that may appear as prenominal attributes, DPs with more than one prenominal adjective are possible; see (19).

T=in man-aj $\quad$ jun-p'éel ko'oj boox k'áanche'.
PFV=A.1sG buy-CMPL[B.3] one-CL.IN expensive black chair
'I bought an expensive black chair.'

Relative clauses follow the head noun. They are syntactic entities of the FP layer: they cannot contain topic constituents and they have the same morphological properties as focus constructions: the aspect/mood auxiliary and the set A marker are dropped when the agent constituent is relativized (Bricker 1979, Bohnemeyer 1998, Tonhauser 2003a, Norcliffe 2009b; see Gutiérrez Bravo 2015 for further types of relative clause in Yucatec Maya); see (20).

$$
\begin{aligned}
& {\left[{ }_{n P}\left[{ }_{n P} \mathrm{~N}\right]\left[{ }_{\mathrm{FP}} \text { op } \mathrm{F}^{\prime}\right]\right]} \\
& \ldots \text { le peek' [chi'-ik-en ka'ach]=o'. } \\
& \text { DEF dog bite-INCMPL-B.1sG formerly=D2 } \\
& \text {... the dog that bit me formerly.' }
\end{aligned}
$$

(Stolz, Stolz \& Verhoeven 2012: 144)

Apart from the attributive adjectives in (18a)/(19), Yucatec Maya has a class of predicative adjectives that always follow the noun. All lexical roots can be used as predicates in Yucatec Maya (see Vapnarsky 2013). Stative predicates appear without aspect-mood inflection and with a 'set B' person marker that is zero in the third person. ${ }^{10}$ Thus, postnominal adjectives are identical to 3rd person predicates that form a relative clause, and can be analyzed as such (Bohnemeyer 1998: 232).

Attributive and predicative adjectives differ with respect to the use of the plural suffix -tak 'ADJ.PL'. ${ }^{11}$ This suffix may optionally appear with predicates, as in (21a); it is obligatory with postnominal adjectives with plural DPs, as in (21b), but is ungrammatical with prenominal adjectives, as in (21c).
(a) $\quad[$ те $\operatorname{Chak}(-$ tak $)$ red-ADJ.PL[B.3sG]
[DP le k'áanche'-o'ob=o']].
'The chairs are red.'
(b) $\mathrm{T}=$ in man-aj [nP k'áanche'-o'ob [FP chak*(-tak)]]. $\mathrm{PFV}=\mathrm{A} .1 \mathrm{sG}$ buy-CMPL[в.3] chair-PL red-ADJ.PL[в.3sG] 'I bought red chairs.'

[10] Beyond adjectives, stative predicates comprise several derived verb forms, e.g. gerundives, resultatives, etc. (see Verhoeven 2007: 121f. and references therein).

[11] This suffix is cognate with plural morphemes in several Mayan languages: a similar data pattern is reported for the indefinite plural -tyak 'PL.INDEF' Ch'ol in Coon (2018), consider also -tak as plural suffix for inanimate nouns and predicative adjectives in Itzá (Hofling 1991: 15, 2000: 179); plural marker -tik in Tsotsil (Aissen 1987); plural morpheme taqe with nouns and -taq with stative predicates in Poqomchi' (Brown 1979: 104f.), etc. 


$$
\begin{aligned}
& \text { (c) } \mathrm{T}=\text { in } \quad \text { man-aj } \quad \text { AP } \operatorname{chak}\left(*^{*}\right. \text {-tak) [nP k'áanche'-o'ob]]. } \\
& \mathrm{PFV}=\mathrm{A} .1 \mathrm{sG} \text { buy-CMPL[B.3] red-ADJ.PL chair-PL }
\end{aligned}
$$

Hence, postnominal adjectives in Yucatec Maya differ from postnominal adjectives in Romance languages that are accounted for through the head movement of the $\mathrm{N}$ (compare Cinque 1994 on Italian). They are rather postnominal predicates (see also semantic tests for the predicative properties of postnominal experiential adjectives in Verhoeven 2007: 157).

\subsection{Apparent discontinuity}

Quantifiers and nouns may appear in a discontinuous linearization, with the noun in the topic position. Examples such as (22) may lead to the conclusion that $\mathrm{nP}$ has been preposed, with the numeral projection moved to the focus position, as in (22a), or stranded as in (22b); see also the continuous option in (22c).

(22) $[\mathrm{CP} \mathrm{nP}[\mathrm{CP}$ op [FP ... [QP [nP pro $]] \ldots]]]$

A: $\{$ Has Pedro bought two tables and two chairs?\}

(a) B: K'áanche'-o'ob=e' óox-p'éel ts'o'ok u man-ik chair-PL $=$ D3 three-CL.IN TERM A.3 buy-INCMPL[B.3] peedróoj*(=i’).

Pedro $=$ LOC

'Pedro has bought THREE chairs.'

(b) B: K'áanche'-o'ob=e' ts'o'ok u man-ik óox-p'éel chair-PL=D3 TERM A.3 buy-INCMPL[B.3] three-CL.IN peedróoj*(=i’).

Pedro $=$ LOC

'Pedro has bought THREE chairs.'

(c) B: Ts'o'ok u man-ik óox-p'éel k'áanche'-o'ob TERM A.3 buy-INCMPL[B.3] three-CL.IN chair-PL peedróoj.

Pedro

'Pedro has bought three chairs.'

In fact, (22a) is much preferred over (22b) by native speakers in contexts licensing a topical noun and a focused quantifier, as illustrated in this example: the nominal projection $k$ 'áanche'-o'ob depicts a member of a list of alternatives available in the Common Ground table, chair\}, while the quantifier of the target utterance is contrasted to the quantifier in the question. As in most other languages of the world, such 'split topicalizations' or 'inverted discontinuous NPs' arise in Yucatec Maya when the two expressions related to the same argument place of the predicate have different pragmatic functions, one being topical, the other being focal. In the absence of any prosodic or morphological focus-marking, foci and topics 
preferentially go to their respective positions. For this reason, (22a) is more in line with the pragmatic preconditions for discontinuity, and therefore preferred (see further discussion in Section 6).

Discontinuous options with a quantifier appearing in the focus position are only possible when the noun simultaneously shows up in the topic position. It is not possible to front focused or $w h$-subconstituents leaving the noun in situ; see (23).
(a) *Jay-p'éel
ts'o'ok u
man-ik
how.many-CL.IN TERM A.3
buy-INCMPL[B.3]
k'áanche'-o'ob
peedróoj(=i')?
Pedro $=$ LOC
Intended: 'How many chairs has Pedro bought?'
(b) A: $\{$ Have you bought a cheap table and cheap chairs?\}
B: $\{$ I have bought a cheap table... $\}$

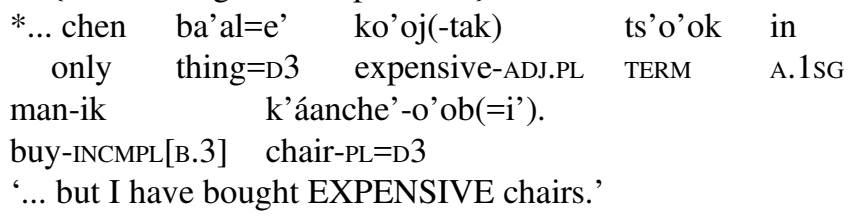
(c) A: $\{$ Has Pedro bought two chairs? $\}$
B: *Óox-p'éel ts'o'ok u man-ik three-CL.IN TERM A.3 buy-INCMPL[B.3] chair-PL
peedróoj(=i').
Pedro=LOC
Intended: 'Pedro has bought THREE chairs.'

The ungrammaticality of the examples in (23) suggests that Yucatec Maya does not allow Left Branch Extraction of the type described, for example, for Slavic languages (Bošković 2005) or Ch'ol (Little 2020). Therefore, the focal numeral in (22a) can hardly be an extracted left branch either, it should rather be analyzed as a complete noun phrase with an empty nominal head.

Split topicalizations/discontinuous noun phrases in Indo-European languages have been the topic of an intense debate in the last decades, a discussion that has been summarized in a lucid way in Ott (2012). There is a research tradition assuming that the noun or a phrase containing it has moved leftward out of the DP in discontinuous constructions, while the other tradition assumes that the discontinuous construction involves two full maximal projections that are generated independently of each other - they are semantically linked to the same argument. In the following, we will argue that the proper analysis of (22) involves two independent DPs, one generated as a left-adjoined topic, the other generated within the clause proper. They are unrelated in terms of syntax, but have a semantic/ pragmatic connection.

A first important observation introduced by the examples in (22) is that the discontinuous options in $(22 \mathrm{a}, \mathrm{b})$ come with the clause-final enclitic $=i$, which is 
absent in the continuous option in (22c). It is worth examining the properties of these enclitics in order to understand their relation to discontinuous constructions. The obligatory presence of these enclitics in $(22 a, b)$ generally appears with nominal projections with an elided head $\mathrm{nP}$.

This enclitic is, in its primary use, a locative anaphor that is obligatory whenever a locative complement of a verb is not overtly realized within the clause, as illustrated in (24). The enclitic is co-indexed with the locative phrase in the topic position.

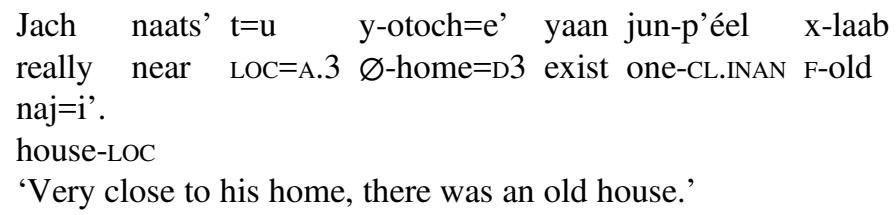

(J-nazario 'Mr. Nazario', 050.1; Lehmann 1989-2019)

The same enclitic occurs obligatorily when the nominal head of a DP is elided. In (25a), an elliptical DP occurs within the thematic layer of the clause, while the elliptical DP in (25b) occurs in the pre-predicate position.

(25) (a) César: \{'Are there no jaguars today?'\}

$\begin{array}{lllll}\text { Mario: } & \text { Yaan, láayli' } & \text { yaan=e', ma' úuch } & \mathrm{k}=\mathrm{u} \\ & \text { EXIST still } & \text { EXIST=D3 NEG long.time } & \text { IPFV=A3 } \\ \text { ts'o'on-ol } & \text { jun-túul=i'. } & & \\ & \text { shoot: } P \text { PASS-INCMPL } & \text { one-CL.AN=LOC } & & \end{array}$

'There are, still there are. It is not a long time ago that somebody shot one of them.'

(Can Canul \& Gutiérrez Bravo 2016: 192)

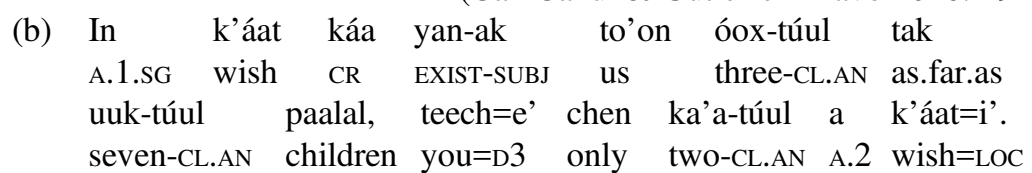

'I wish to obtain three to seven children, but you wish only two of them.' (Academia de la Lengua y Cultura Mayas de Quintana Roo 2007: 45)

The enclitic $=i$ ' belongs to a class of enclitics that must appear at the right edge of the CP (see Skopeteas 2010), which accounts for the linearization in (25b), in which the enclitic is not adjacent to the DP in the focus position.

With this background, we now return to the occurrence of the enclitic $=i$ ' ' $\mathrm{LOC}$ ' in discontinuous noun phrases. The enclitic is obligatory if the nominal head is left adjoined, as in (26a), but can be only used with a locative interpretation (as a locative adjunct co-referring to a place in the context) if the nominal head is within the thematic layer of the clause as in (26b). 
(a) A: \{Did Pedro read any books? $\}$
B: Áanalte'-o'ob=e' ya'abkach ts'o'ok u xok-ik book-PL=D3 many TERM A.3 read-INCMPL[B.3] peedróoj*(=i').
Pedro $=$ LOC
'As for books, Pedro has read many of them.'
(b) Peedróoj=e' $t=u \quad$ xok-aj ya'abkach áanalte'-o'ob(=i'). Pedro $=\mathrm{D} 3 \quad \mathrm{PFV}=\mathrm{A} .3$ read-CMPL[B.3] many book $-\mathrm{PL}=\mathrm{LOC}$
'Pedro has read many books (there).'

Basically, two analyses are available for this constellation. The use of the locative marker with elliptical noun phrases ${ }^{12}$ is reminiscent of the use of partitive clitics such $n e$ in Italian, en in French, etc. with noun phrases that lack an overt head. A standard analysis appears to be that $e n$ is generated below the numeral within the direct object DP, and then undergoes subextraction to the clitic position. The compatibility of $e n$ with a stranded adjective suggests that $e n$ corresponds to an $\mathrm{nP}$. Such nP-pronouns can either derive their interpretation from the context, as in (27a), or from a left-adjoined constituent, as in (27b).

(27) (a) (De gravures flamandes,) j' en ai acheté trois. of engravings Flemish 1sG EN have bought three 'I have bought three (of the Flemish engravings).'

(b) Parmi mes copains, il y en a plusieurs vieux. among my friends, 3sg here EN have many old 'Among my friends, there are many old ones.'

It is tempting to assume that French $e n$ and Yucatec Maya $=i$ ' have, basically, the same analysis. The left-peripheral topic would then bind the $=i$ ' and $e n$ in the same way. For French and Italian, the movement analysis for the clitic derives some support from the fact that the construction is fine for direct objects and unaccusative subjects only, i.e. its derivation appears characterized by a Condition on Extraction Domain (CED) effect (see Section 1; footnote 4). The enclitic $=i$ ' in Yucatec Maya is not sensitive to CED effects, as shown by the adjunct split in (28).

(28) A: \{Felipe is a colonel and is accompanied by soldiers. How many soldiers does he walk with?\}

B: Waach-o'ob=o' feliipéej=e' yéetel óox-túul $\mathrm{k}=\mathrm{u}$ máan=i'. soldier-PL $=\mathrm{D} 2$ Felipe $=\mathrm{D} 3$ with three-CL.AN $\mathrm{IPFV}=\mathrm{A} .3$ pass $=\mathrm{LOC}$ 'Felipe is walking around with THREE soldiers.'

[12] Consider also the partitive interpretation of the same enclitic with numeral classifiers and elided nominals in Itzá Maya in Hofling (2000: 145). 
The relation between the DP and the enclitic does not need to be created by movement in this language. Partitive constructions involve an empty pronominal pro that needs to be licensed, with the locative enclitics in Romance and Yucatec Maya fulfilling that function in possibly different ways (see a proposal along these lines by Saez 1991 considering Slavic clitics).

The conclusion from these facts is that left-adjoined nPs pattern with elided nPs. In both cases, a locative enclitic appears in the clause with an anaphoric relation to an antecedent outside the FP layer. Assuming that the enclitic is an anaphor, we may understand the examples in (26) through a partitive paraphrase of the kind 'books... many of them'. The clitic example thus supports the view that the two parts of the 'discontinuous' construction are actually two DPs independent of each other. In particular, the left-adjoined phrase has not been extracted from the DP in the clause proper.

If this view is correct, we expect to find sentences in which the nominal part of the right DP is not elided. This expectation is indeed fulfilled, as (29) shows.

$$
\begin{array}{lllll}
\text { Cooches-o'ob=e' leti'=e' } & \text { chen } & \text { Toyotas } \mathrm{k}=\mathrm{u} & \text { man-ik. } \\
\text { car-PL=D3 } & \text { that.one= }=\mathrm{D} 3 & \text { only } & \text { Toyota:PL IPFV=A.3 } & \text { buy-INCMPL[B.3] } \\
\text { 'As for cars, he only buys Toyotas.' } & & &
\end{array}
$$

For the 'discontinuous' construction to be well-formed, it seems as if the extension of the left-adjoined nominal must be a superset of the noun phrase in the focus position (which is always the case if, as in the case of an elliptical noun, there are no referential restrictions at all on left-adjoined constituents).

The following mismatches between the parts of the discontinuous construction strengthen this view and offer counterevidence to an analysis of SPLIT TOPICALIZATION as extraction of a subconstituent out of a continuous DP. One mismatch of this type is DETERMINER OVERLAP. The left-adjoined head as well as the alleged remnant may host their own determiner, while the corresponding continuous noun phrase with two determiners is not well-formed; see (30a, b).

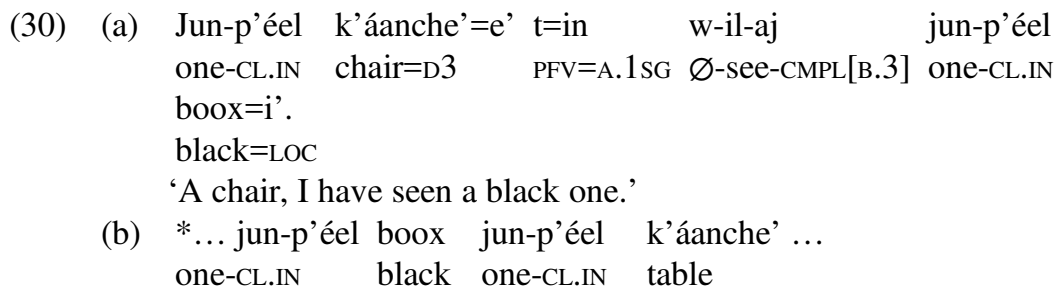

Agreement mismatches lend further support to the postulation of two DPs independent of each other. The second conjunct in (31a) comes with a left dislocated noun phrase in plural. The remnant numeral cannot modify a plural noun, i.e. (31b) is not a possible noun phrase. 

(a)

$\begin{array}{ll}\text { K'áanche'-o'ob=e' } & \text { óox-p'éel } \\ \text { chair-PL=D3 } & \text { three-CL.IN } \\ \text { meesáaj-o'ob=e' } & \text { jun-p'éel } \\ \text { table-PL=D3 } & \text { one-CL.N }\end{array}$
$\mathrm{t}=$ in $\quad$ man-aj=i',
$\mathrm{PFV}=\mathrm{A} .1$ buy-CMPL[B.3]=LOC
table-PL $=\mathrm{D} 3$
one-CL.IN
$\mathrm{t}=$ in $\quad$ man-aj=i'.
'I bought three chairs and I bought one table.'
(b) *... jun-p'éel meesáaj-o’ob ...
one-CL.IN table-PL

Examples with a pluralized topic and a pluralized remnant are possible with discontinuous noun phrases, as in (32a), although pluralized quantifiers are excluded in continuous nominal projections, as in (32b) (the plural suffix could only appear twice in the same nominal projection with postnominal adjectives; see Butler 2012: 37).
(a) A: $\{$ Did two girls hit you? $\}$
B: X-ch'úuppalal-o'ob=e' k=u jats'-ik-en óox-túul-o’ob=i'. F-girl:COLL-PL $=\mathrm{D} 3 \quad \mathrm{IPFV}=\mathrm{A} .3$ hit-INCMPL-B. $1 \mathrm{sG}$ three-PL $=\mathrm{LOC}$
'ThreE girls hit me.'
(b)

If the discontinuous noun phrases are not generated by a movement process, as suggested by the mismatches we have presented, they should not be sensitive to island effects, as already shown in (28) above: the topic phrase is linked to an adjunct in the clause proper, which would be expected to block subextraction (in terms of the CED).

Under the analysis of discontinuous noun phrases in terms of two independently generated maximal projections, there should be no syntactic constraints on the actual composition of either of the two parts of the discontinuous construction. Adjectives and quantifiers can appear as topics as well, in which case they form a nominal projection with elided nominal head. The contextual conditions for such constructions are highly restricted, since they require the topicalization of a quantified/modified nP with head ellipsis (additionally to the contextual conditions of discontinuity). Such contexts are illustrated in (33a) with a left-adjoined adjective and in (33b) with a left-adjoined quantifier (elliptical possessor phrase).
(a) A: $\{$ Did you buy two black chairs? $\}$
B: Bóox-tak=e' óox-p'éel ts'o'ok in man-ik=i'. black-ADJ.PL $=\mathrm{D} 3$ three-CL.IN TERM A.1 buy-INCMPL[B.3]=LOC 'Concerning black ones, I have bought three.'
(b) Jun-túul=e' chak u nak'... three-CL.AN=D3 red A.3 belly
'One (of them) has a red belly ...'
(lit.: 'concerning one of them, his belly is red')

(Collí Collí et al. 2007: 85) 
Yucatec Mayan topic phrases do not reconstruct for binding, as seen in (12). In the same vein, possessed DP subconstituents in the topic position are only felicitous if the possessor is co-indexing an antecedent established through the context, as in (34a), but they cannot reconstruct a binding relation to a binder within the thematic layer of the clause, as in (34b).

(34) (a) \{There was a farmer who sent three men to sell his chicken in the market.\}

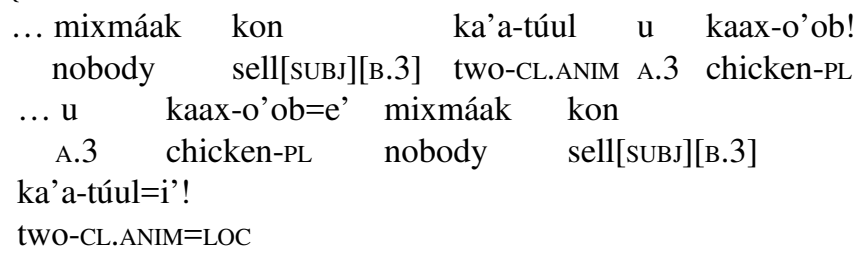

'Nobody sold two of his (=of the farmer) chicken.'

(b) \{There were three farmers who went to sell their chicken in the market.\}

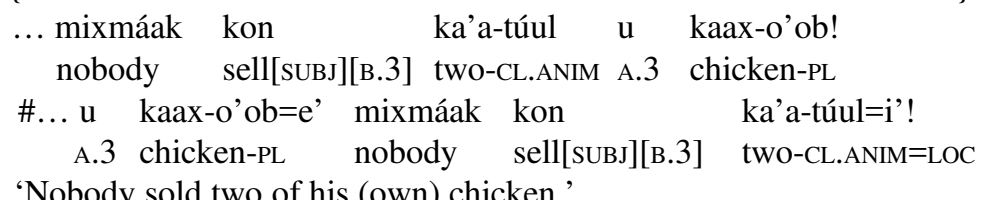

In this section, we have shown that the apparent cases of discontinuity with a nominal head in the topic position and a quantifier within the thematic layer of the clause are not derived by subextraction out of a single noun phrase in situ. Yucatec Maya tolerates non-referential topics in the left-peripheral position that define a set of entities relative to which the assertion has to be evaluated. When the argumental expression to which this topic is related comes with an elliptical noun (as it mostly does), the impression of the discontinuity of a single DP arises in a construction that in reality involves two independent nominal projections. This view is corroborated by the presence of locative anaphors and several types of mismatches that do not appear with the corresponding continuous constructions, by the fact that the possible topics are not restricted by conditions on extraction domains and finally by the lack of reconstruction effects. This result is in line with the properties of left-adjoined topics in general (lack of agent focus morphology with left-adjoined agents, lack of reconstruction, see Section 2).

\section{Nouns in the focus position}

While (real or apparent) discontinuous noun phrases usually arise in a pragmatic context in which the left part is the (contrastive) topic and the right part the focus, other contexts have been shown to license discontinuity as well (see e.g. Féry, Paslawska \& Fanselow 2007). In particular, the left part of a discontinuous construction can be the focus and the right element can belong to the given information; see German in (35). 

A: $\{$ Does he have many friends?\}
B: Nein, FEINDE hat er viele. no enemies has he many
'No, he has many ENEMIES.'

Féry et al. (2007) and Fanselow (2013) have pointed out that there are certain morphological differences between the topic-focus and the focus-given types of discontinuity, and Fanselow (2013) argues for a syntactic difference bringing about both the morphological and the pragmatic facts: the topic-left type involves two independent DPs (as discussed above), while the focus-left type comes about by moving nP out of DP.

The clear distinction between topic and focus positions in Yucatec Maya allows us to study the impact of information structure on properties of discontinuous constructions in quite a direct way. As shown by (36), an adjective-noun combination can be placed into the focus position, stranding a quantifier in the postverbal domain (the nature of the preverbal slot for ma'alob áanalte' $o$ 'o $b$ is identified by the lack of a topic marker to its right).

(36) A: \{Has Pablo read many bad books?\}

B: Leti'=e' ma'alob áanalte'-o'ob ts'o'ok u xok-ik

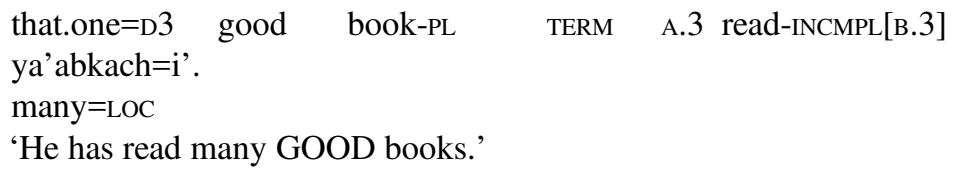

When a transitive subject is split up in such a way that the left element is a (contrastive) focus, we expect the construction to show agent focus properties. The dialogue in (37) confirms this prediction.
A: $\{$ Did three boys hit you? $\}$
B: Ma'! X-ch'úuppal-o'ob jats'-ik-en óox-túul=i'.

Given that the focus position is arguably filled by a movement process, the placement of an nP there should not come with the properties that suggested the generation of two independent DPs in the discontinuous topic-focus construction. Indeed, determiner overlap is impossible when $\mathrm{nP}$ is a focus, as seen in (38), in contrast to what we found in split topicalization; compare (30a) above.

$$
\begin{aligned}
& \text { *Jun-p'éel k'áanche' t=in w-il-aj } \quad \text { jun-p'éel boox=i'. } \\
& \text { one-CL.IN chair } \quad \text { PFV=1sG } \varnothing \text {-see-CMPL[B.3] one-CL.IN black=LOC } \\
& \text { Intended: 'A CHAIR, I have seen a black one.' }
\end{aligned}
$$

Agreement mismatches as discussed in connection with (31a) also cannot be observed for the placement of an $\mathrm{nP}$ in the focus position. The examples in 
(39) contain a noun in the focus position, while the numeral in the postverbal domain is part of the given information (the focus domain of the context question is underspecified). The fronted noun may bear plural morphology when sitting in the focus position, as seen in (39a), but only when the numeral left behind is itself semantically plural. In case the numeral is 'one' as in (39b), the nP cannot bear plural morphology, in contrast to what we have observed with the placement of the noun in the topic position in (31a), in which case agreement mismatch is tolerated.

(a) A: $\{$ Did you buy three chairs? $\}$
B: Ma'! Meesáaj-o'ob $t=$ in NEG table-PL $\quad$ PFV $=$ A. 1
man-aj
buy-CMPL[B.3]
óox-p'éel=i'.
'No! I bought three TABLES.'

(b) A: \{Did you buy one chair?\}
B: Ma'! Meesáaj(*-o'ob) t=in man-aj jun-p'éel=i'. NEG table-PL $\quad \mathrm{PFV}=\mathrm{A} .1$ buy-CMPL[B.3] one-CL.IN=LOC 'No! I bought one TABLE.'

Examples (38) and (39) thus lend strong support to the view that the differences in the information-structural properties of the noun in the discontinuous construction go hand in hand with a difference in derivation: in the topic-focus construction, the two parts of the constructions are full maximal projections generated independently of each other, while the focus has been extracted from a DP stranded in situ in the focus-given construction.

There is a complication, however: the focus-given construction also requires the presence of the locative clitic $=i$; ; see the contrast in (40).
A: $\{$ Are three boys hitting you?\}

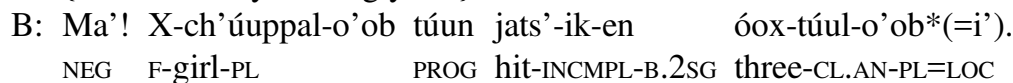
'No! Three GIRLS are hitting me.'

Recall that the clitic is indicative of a DP with an empty nominal head. While such a DP is present in (40), the occurrence of the clitic is surprising because the noun linked to the numeral is also present in FP. Given that we have seen above that phrases in Spec,FP are visible for the determination of the placement of the locative version of $=i$, we would expect the same to hold in the case of its partitive version, in contrast to (40). If $=i$ ' is a licenser for an empty $\mathrm{nP}$ (as envisaged in Section 3.2), one wonders why it would have to be present when the empty $\mathrm{nP}$ is a trace rather than pro, and why the movement antecedent could not itself license its gap. If $=i$ ' is subextracted from DP, the constellation in (40) appears even more miraculous, because $=i$ ' and $x c h$ 'úuppalo' $o b$ would have had to move from the very same position.

There appears to be no straightforward answer as to why the clitic appears in both discontinuous constructions that would not substantially increase the complexity of the analysis, so we confine ourselves to stating that the clitic must occur whenever the head of a DP is phonetically unrealized, be it a pro or a trace. 
This section dealt with a class of discontinuous noun phrases with a nominal head in the focus position and a quantifier in the postverbal domain. This construction differs from split topicalization (Section 3.2) in that it does not allow for morphological mismatches. The only mismatch is the presence of a locative enclitic after focus movement: this enclitic is evidence for a step in the derivational history in which the remnant quantifier behaves like an elliptical nominal projection that must be licensed. In order to understand the properties of this construction, we need to examine the properties of possessor extraction and related constructions in Section 5. Compared with the findings in Section 3.2, it seems that subextraction out of nominal structures is possible in Yucatec Maya, but not out of a left branch. In the model proposed by Bošković (2005), this comes as no surprise, since Yucatec Maya possesses definite determiners (see Vázquez-Rojas Maldonado et al. 2018) and allows for multiple adjectives in front of the noun, thereby fulfilling two of the criteria that rule out Left Branch Extraction in this model.

\section{Possessors and Related Categories}

This section examines discontinuous structures with possessors, partitives and embedded PPs. These constructions offer further support for the contrast between topics and foci that has been introduced in the previous sections. Furthermore, these constructions allow us to test some hypotheses about the derivational history of discontinuous structures.

\subsection{Preliminaries}

Nominal projections (nP) have a structure parallel to vP: similarly to subjects, possessors follow the N-head and are coindexed by a set A marker (see discussion of Tz'utujil in Abney 1987: 31; Tsotsil in Aissen 1996: 454ff.; Ch'ol in Coon 2008). In Yucatec Maya, possessor DPs follow the head noun and are not casemarked; the head noun is accompanied by a set A person marker, whose phifeatures are valued by the embedded possessor (Lehmann 2002; Armstrong 2017: 162); see (41).

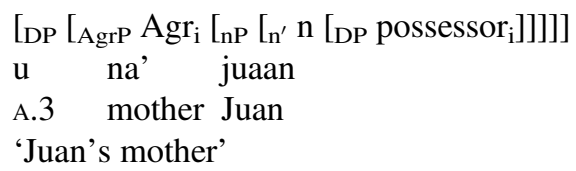

Possessors are dealt with as specifiers of the $\mathrm{n}^{\prime}$ layer (Aissen 1996: 258). Like subjects, they are co-indexed with set A marker.

DP-subconstituents that are in focus or bear a $<$ wh $>$ feature can pied-pipe the dominating maximal projection (Lehmann 2002: 29; Gutiérrez Bravo 2015: 61) when they go to Spec,FP; see (42). 

[U na' $\left.\quad[\operatorname{máax}]_{<w h>}\right]$ ts'o'ok a w-il-ik?
A.3 mother who TERM А.2 $\varnothing$-see-INCMPL[B.3]
'Whose mother have you seen?'

The $<w h>$ feature of the embedded DP leads to movement of the encompassing DP to Spec,FP (the same phenomenon applies to focus). Hence, feature-movement is determined by some convergence principle ${ }^{13}$ to the effect that the entire extended projection that encompasses the feature-bearing entity is attracted to the Spec,FP (but see pied-piping and inversion in Section 5.3 below).

\subsection{Evidence for movement}

Apart from the pied-piping construction just introduced, DPs with possessors can also come to be linearized in a discontinuous fashion in various ways in Yucatec Maya. Beside topicalized possessors as in (1), possessors can occur in the prepredicate position, while the possessed head remains in situ; see $w h$-movement in (43a), and focus movement in (43b) (see Aissen 1987: 13f. on Tsotsil).
(a) Máax ts'o'ok a $_{\mathrm{i}}$ w-il-ik $\mathrm{u}_{\mathrm{i}}$ na'? who TERM A.2 $\varnothing$-see-INCMPL[в.3] A.3 mother 'Whose mother have you seen?'

(b) $\{$ I did not see both the mother of Pedro and the mother of Juan ... $\}$
$\ldots$ chen peedróo $j_{i} t=i$
w-il-aj
$\mathrm{u}_{\mathrm{i}}$ na'. only Pedro
$\mathrm{PFV}=\mathrm{A} .1 \mathrm{sg} \quad \varnothing$-see-CMPL[в.3]
A.3 mother
'... I saw only PEDRO's mother.'

Discontinuous possessive constructions are reported for several Mayan languages. Examples of the construction in (1) above with a topical possessor and a noun in the clause proper have been reported for Tz'utujil (Dayley 1985: 327), Poqomchi' (Brown 1979: 141), Itzá (Hofling 2000: 208), and Yucatec Maya (Lehmann 2002: $39,109)$; examples with a focal possessor DP and a nominal head in situ such as (39b) have been reported for Tsotsil (Aissen 1996: 456), Ch'ol (Coon 2009: 166; Little 2020: 25), and K'iche' (Broadwell 2005: 6).

$\bar{A}$-movement of the possessor phrase to the focus position is expected to observe conditions on extraction. As a starting point, we assume the Condition on Extraction Domain, as stated by Huang (1982: 505); see footnote 4. Aissen (1987: 178, 1996: 460f.) confirms the predictions of the CED in possessor extraction in Tsotsil: extraction is possible out of DPs that are properly governed, i.e. objects of transitives and subjects of unaccusatives and not out of adjuncts or subjects of transitive/unergative verbs (Aissen 1996: 460f. on Tsotsil; Coon 2010: 227 on Ch'ol; see also Little 2020 for restrictions on extraction out of shifted objects in

[13] Several such principles have been proposed in the literature on pied-piping; for instance, stating that the local application of Agree is preferred over a remote one (Heck 2009: 75). 
Ch'ol). The examples in (43) confirm that possessor extraction out of objects of transitive verbs is possible. However, extraction of the possessor DP is not possible out of adjuncts, which is in line with the CED generalization; see (44).

*Máax táan a xíimbal yéetel u suku'un?

who PROG A.2 walk with A.3 elder.brother

'With the brother of whom are you walking?'

The discontinuous option with left adjunction is, as expected, not sensitive to this constraint, as seen in (45) for possessive constructions with a left-adjoined possessor.

(45) A: \{Do you have any news from Pedro?\}

B: $P$ Peedróoj ${ }_{i}=e^{\prime} j$ ximbal-naj-en yéetel $u_{i}$ suku'un.

Pedro $=$ D3 PFV walk-CMPL-B.1sG with A.3 elder.brother 'As for Pedro, I walked with his elder brother.'

The contrast between (44) and (45) offers additional support for the predictions in (16): phrases in the immediately preverbal focus position have undergone $\bar{A}$-movement, while topics are first merged at the left periphery of the clause.

Subextraction out of subjects of transitive verbs is rejected in Tsotsil (Aissen 1996: 460), and Ch'ol (Coon 2010: 227; Bale, Coon \& Arcos López 2019: 19-20). Yucatec Maya differs from these languages in allowing for possessor extraction out of specifiers. It is possible to extract a subconstituent of the subject of a transitive verb, as in (46a), as well as out of the subject of unergatives independently of agreement; see set A agreement/incompletive aspect in (46b) and set B agreement/ completive aspect in (46c).
(a) Subject of transitive verb

$\begin{array}{lllll}\text { Máax } & \text { jaan-t } & \text { oon } & \text { u } & \text { na'? } \\ \text { who } & \text { eat-TRR[SUBJ][B.3] } & \text { avocado } & \text { A.3 } & \text { mother }\end{array}$
'The mother of whom eats avocado?'
(b) Subject of intransitive verb (set A cross-reference marker)

$\begin{array}{lllll}\text { Máax táan u jaan-al } & \text { u } & \text { na'? } \\ \text { who PROG A.3 eat-INCMPL[B.3] } & \text { A.3 } & \text { mother } \\ \text { 'The mother of whom is eating?' } & & \end{array}$
(c) Subject of intransitive verb (set B cross-reference marker)

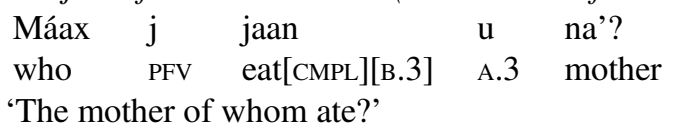

Assuming that split intransitivity correlates with a thematic difference, the data lead to the conclusion that Yucatec Maya does not display a subject/object asymmetry in subextraction (the grammaticality of possessor extraction with unergatives/unaccusatives is also reported for K' iche', Broadwell 2005: 20; extraction out of subjects of transitives is also possible in Tseltal, Polian 2013: 231). 
Yucatec Mayan is not the only language that does not fulfil the predictions of the subject island condition. Possessor extraction out of subjects/objects but not out of adjuncts is reported for Italian (Longobardi 1991: 74), Indonesian and Javanese (Jeoung 2016: 7), and XPs can be extracted from nominatives/accusatives but not from genitives/datives in German (Fanselow 1988: 102); see the cross-linguistic overview in Stepanov (2007). The key to understanding these facts seems to be that subjects appearing in relatively low positions in the clause (e.g. specifier of vP) are more likely to be transparent than subjects in higher positions (such as e.g. specifier of TP). This view offers an account for the absence of subject/object asymmetries in subextraction in Yucatec Maya, K'iche' and Tseltal, but does not explain the presence of subject island effects in Tsotsil and Ch'ol. Furthermore, subject island effects are strong only in those languages in which the direct object and the verb must be string-adjacent (see Haider \& Szucsich 2020), which is not the case in Yucatec Maya; see (4) above.

As introduced in Section 2, the movement of the subject of a transitive verb triggers a particular inflectional form of the verb (agent focus). Interestingly, this inflectional form also appears with possessors extracted out of subjects of transitive verbs; see (47).
(a) Máax il-ech
u na'?
who see[suBJ]-B.2sG A.3 mother
'The mother of whom saw you?'
(b) Chen peedróoj il-en u na'.
only Pedro see[suBJ]-B.1sG A.3 mother
'Only Pedro's mother saw me.'

These examples indicate that the thematic properties of the encompassing DP are visible in these constructions.

A simple way of capturing such data is to assume that agent focus morphology is chosen whenever an element in the preverbal focus position has a binding relation with a trace in the transitive subject position (irrespective of whether the trace is further embedded there or not); see Norcliffe (2009b). The choice of agent focus agreement for a raised possessor of an agent can be understood in terms of agreement mismatches, as reported for several languages; agreement may be influenced by features of several layers of the nominal structure. For instance, agreement with X can refer to properties of the possessor of $\mathrm{X}$ in certain languages such as Maithili (Stump \& Yadav 1988, Bickel, Bisang \& Yādava 1999), Tseltal (Shklovsky 2012), or control structures in Yucatec Maya (Verhoeven 2007: 275).

Summing up, the syntactic properties of left-peripheral positions are reflected in discontinuous constructions with possessor DPs in Yucatec Maya. The relation between possessors in the topic position and the possessed entity in the proper clause is not sensitive to island constraints, which confirms the prediction about topics in (16b). Possessors in the focus position are sensitive to island constraints and may trigger the agent-focus morphology, which is in line with the view that 
these constructions result from Ā-movement; see (16a). Postverbal subjects are not islands for extraction in Yucatec Maya, which supports the view that these subjects are within the thematic layer of the clause, as seen in (5).

\subsection{Cyclic movement out of DP?}

In certain models, the subextraction of a possessor comes about by successive cyclic movement (from specifier-to-specifier): it moves first to the specifier position of the $\mathrm{DP}$, and from there to the left-peripheral specifier position of a functional projection $\mathrm{FP}$, as seen in (48). Such a model must be supported by evidence showing that the possessor may indeed move to Spec,DP, which has been demonstrated for several languages (Horrocks \& Stavrou 1987 on Greek; Longobardi 1991 on Italian; Szabolcsi 1994: 181 on Hungarian; Aissen 1996 on Tsotsil; Yucatec Maya in Armstrong 2017: 163).

$$
\left[\mathrm{CP}\left[\mathrm{FP} D P_{\mathrm{i}}\left[\mathrm{TP} \ldots\left[{ }_{\mathrm{DP}} t_{\mathrm{i}}\left[\mathrm{D}^{\prime}\left[\mathrm{nP}_{\mathrm{N}} \mathrm{N} t_{\mathrm{i}}\right]\right]\right] \ldots\right]\right]\right]
$$

Several Mesoamerican languages provide evidence that possessor phrases may be hosted by a specifier position at the left edge of the D-layer under particular conditions. The construction at issue is a particular instance of pied-piping, known as 'pied-piping and inversion' (see Smith Stark 1988 for Mesoamerican languages; Grinevald Craig 1977: 15 on Jakaltek; England 1983: 252 on Mam; Aissen 1996: 457 on Tsotsil and Coon 2009 on Ch'ol): when a wh-possessor is pied-piped to the specifier of the FP, the basic order 'possessed > possessor' is inverted to 'possessor > possessed'. In Yucatec Maya, this type of inversion is optional (Lehmann 2002: 40f.; Tonhauser 2003b; Gutiérrez Bravo 2015: 61). Both linearizations in (49) are acceptable, while speakers judge the possessed-possessor order in (49a) as the preferred option. ${ }^{14}$
(a) U na'(*-il) máax il-ech? A.3 mother(-REL) who see[SUBJ]-в.2SG
'The mother of whom saw you?' (well-formed; preferred option)
(b) Máax na*(-il) il-ech?
who mother-REL see[SUBJ]-B.2SG
'The mother of whom saw you?'

The inverted linearization is accompanied by an inflectional change, which is reminiscent of the agent focus construction; the agreement marker is dropped and the head noun must appear in a particular inflectional form, suffixed with -il 'REL'; see $(49 \mathrm{~b}) .{ }^{15}$ This inflectional form is rejected in the linearization possessed-

[14] Both options occur in texts, e.g. máax yéetel $k=u$ tsikbal (who with $\mathrm{IPFV}=\mathrm{A} .3 \mathrm{chat}$ ) 'With whom is he chatting?' (Monforte, Dzul \& Gutiérrez Bravo 2010: 270), and yéetel máax $k=i n$ p'áatal? (with who IPFV=A.1 stay) 'With whom am I staying?' (Can Canul \& Gutiérrez Bravo 2016: 39). The choice of linearization is not predictable by the meaning of the question.

[15] The same morphological pattern appears with alienable nouns, e.g. máax áanalte'-il (who bookREL) 'the book of whom'. 
possessor; see (49a). This contrast provides evidence for a specifier position at the outer layer of the extended projection of the noun (see Aissen 1996: 464). In Yucatec Maya, this construction shows particular inflectional properties. The fact that possessors may move to a specifier position at the left edge of the DP raises the question of whether instances of discontinuity with possessors can be explained in terms of successive cyclic movement as sketched in (48). Furthermore, if movement to the Spec,FP мust be mediated by Spec,DP, then a cyclic movement account would promise an explanation for the fact that extraction is possible for possessor DPs but not for adjectives and quantifiers (see Section 3), since the former but not the latter may appear in the Spec,DP.

However, only a subset of the possessors that can be extracted to the Spec,FP in Yucatec Maya are also eligible for this type of inversion in DP. Crucially, inversion can be triggered by a $<w h>$ feature, as in (50a), but not by focus, as seen in (50b), which is not reflected in the discontinuous options, since focused possessors can be subextracted, as in (43b).
(a) U na'
peedróoj il-en.
A.3 mother Pedro see[suBJ]-в.1sG
'It is Pedro's mother who saw me.'
(b)

$\begin{array}{lll}\text { *Peedróoj na'-il } & \text { il-en. } \\ \text { Pedro mother-ReL } & \text { see[suBJ]-в.1sG } \\ \text { Intended: 'It is PEDRO's mother who saw me.' }\end{array}$

Second, possessor inversion in Yucatec Maya is obligatorily accompanied by the suffixation of $-i l$ to the head noun; see (49b). Crucially, this morphological form is not grammatical in the discontinuous option; see (51).
Máax il-ech
u na' $^{\prime}(*-1)$ ?
who see[sUBJ]-в.2sG A.3 mother-REL
'The mother of whom saw you?'

Hence, the morphological facts indicate that the discontinuous option is not mediated by a derivational step with the possessor at the Spec,DP.

The data of this section provide two problems for the analysis of discontinuous patterns in terms of successive cyclic movement of the possessor DP through the escape hatch of the DP. The discontinuous options can be licensed by features like $<$ focus $>$ that do not license inversion in possessive structures. Second, the form of the possessed noun in sentences with possessor subextraction does not have the inflectional properties that are expected for possessors raised at the specifier position of the DP.

\subsection{Extraposition}

The possibility of adverbs intervening between DP subconstituents at the right edge of the clause proper is evidence that a part of the DP can be extraposed to the right. 
This test reveals a left/right asymmetry within the projection of nouns. Possessors can be separated from the host noun by a temporal adverb; see (52).
$\mathrm{T}=$ in $\quad$ w-il-aj
u na' jo'olje'ak
peedróoj.
$\mathrm{PFV}=$ A.1sG $\varnothing$-see-CMPL[B.3] А.3 mother yesterday Pedro
'I saw the mother of Pedro yesterday.'

Right extraposition is not possible for heads of the left branch of the nominal projection. Numerals cannot be extraposed, as seen in (53a), while adjectives can only be extraposed with the plural suffix -tak 'ADJ.PL', as in (53b), which is only possible for predicative (postnominal) adjectives, as seen in (21) above.

$$
\begin{aligned}
& \text { (a) *Maariáaj=e' t=u kaxt-aj k'áanche'(-o'ob) jo'olje'ak } \\
& \text { Maria=D3 PFV=A.3 search-CMPL[B.3] chair-PL yesterday } \\
& \text { óox-p'éel. } \\
& \text { three-CL.IN } \\
& \text { Intended: 'Maria searched for three chairs yesterday.' } \\
& \text { (b) Maariáaj=e' t=u kaxt-aj k'áanche'-o'ob jo'olje'ak } \\
& \text { Maria=D3 PFV=A.3 search-CMPL[B.3] chair-PL yesterday } \\
& \text { chak*(-tak). } \\
& \text { red-ADJ.PL }
\end{aligned}
$$

The locus of adjunction can be tested through CP-final clitics; see (13)-(15). Crucially, the examples of right extraposition become ungrammatical if we insert a clitic at the right edge of the adverb (the judgment illustrated in (54) for possessors also applies to postnominal adjectives).
$*[\mathrm{~T}=\mathrm{in} \quad \mathrm{w}-\mathrm{il}-\mathrm{aj}$
u na' jo'olje'ak=e' $]_{C P}$ peedróoj.
$\mathrm{PFV}=$ A.1SG $\varnothing$-see-CMPL[B.3] A.3 mother yesterday=D3 Pedro
Intended: 'I saw the mother yesterday, namely Pedro's (mother).'

Thus, we conclude that the facts in $(52) /(53 \mathrm{~b})$ involve adjunction to a lower layer, presumably the TP.

An intervening adverb must not separate elements to the left of the noun from a constituent containing the noun, as seen in (55).

\footnotetext{
(a) $* \mathrm{~T}=$ in $\quad$ w-il-aj le óox-p'éel jo'olje'ak mejen $\mathrm{PFV}=\mathrm{A} .1 \mathrm{SG} \quad \varnothing$-see-CMPL[B.3] DEF three-CL.IN yesterday small naj-o'ob $=$ o'.

house-PL $=\mathrm{D} 2$

Intended: 'I saw the three small houses yesterday.'
(b) $* \mathrm{~T}=$ in $\quad \mathrm{w}$-il-aj le óox-p'éel mejen jo'olje'ak $\mathrm{PFV}=\mathrm{A} .1 \mathrm{SG} \quad \varnothing$-see-CMPL[B.3] DEF three-CL.IN small yesterday naj-o'ob $=$ o'.
house-PL $=\mathrm{D} 2$
Intended: 'I saw the three small houses yesterday.'


The examples in (55) would be grammatical if the temporal adverb jo'olje'ak was placed clause-finally. Apparently, XPs forming part of the extended projection of the noun cannot be moved rightwards out of this extended projection (NP, AP, and NumP cannot be extraposed from DP), while complements, adjuncts and specifiers of the noun can. Extraposition seems to affect full referential XPs only, a constraint that is in line with what we find in other languages.

When the possessor is extraposed from DP, the remnant DP can undergo movement to the preverbal focus position, as shown in (56).

(56) \{It was not the father and the mother of Pedro, who saw me ... $\}$

$\begin{array}{lllll}\text { Chen } & \text { u } & \text { na' } & \text { il-en } & \text { peedróoj. } \\ \text { only } & \text { A.3 } & \text { mother } & \text { see[SUBJ]-в.1sG } & \text { Pedro }\end{array}$

'Only the MOTHER of Pedro saw me.'

The acceptability of the construction is predicted, because there is reconstruction for binding from the Spec,FP position; see (11). The trace left by the extraction of the possessor in the DP thus continues to be properly bound by its antecedent even if the DP has undergone further operator movement. In contrast to the FP layer, there is no reconstruction for binding into $\mathrm{CP}$ proper, as seen in (12). Correspondingly, sentences with the possessed nominal in the topic position are rejected, either with a possessor in the focus position or in the postverbal domain; see (57a, b).
(a) $* \mathrm{U}_{\mathrm{i}}$
na' $=e^{\prime}$
juaan $_{\mathrm{i}}$ táan
u xok-ik
A.3
mother $=\mathrm{D} 3$
Juan
PROG
A.3 read-INCMPL[B.3]
jun-p'éel áanalte'.
one-CL.IN book
'The mother of Juan is reading a book.'
(b) ${ }^{*} \mathrm{U}_{\mathrm{i}}$ na'=e' t=in w-il-aj juaan $_{\mathrm{i}} \quad \mathrm{y}$-éetel
A.3 mother $=$ D3 $\quad$ PFV=A.3 $\varnothing$-see-CMPL[в.3] Juan $\varnothing$-and
$\mathrm{u}_{\mathrm{i}} \quad \mathrm{suku} u n=\mathrm{e}$, $\mathrm{t}=\mathrm{in} \quad \mathrm{w}$-il-aj $\quad$ peedróoj $\mathrm{j}_{\mathrm{i}}$.
A.3 elder.brother=D3 PFv=A.3 $\varnothing$-see-CMPL[в.3] Pedro
'I saw Juan's mother and I saw Pedro's elder brother.'

It is not only possessors and relative clauses that can be detached from DP by movement. There are two further relevant constructions of this type: partitive DPs and adjunct PPs embedded in DP constituents. Partitive DPs are formed by definite phrases following a quantifier; the syntactic relation between the partitive phrase and the head nominal is spelt out neither by agreement on the head nominal nor by case; see (58).

$$
\begin{aligned}
& \mathrm{T}=\mathrm{in} \quad \operatorname{man}-\mathrm{aj} \quad \text { óox-p'éel le áanalte'-o' } \mathrm{ob}=\mathrm{O} \text { '. } \\
& \mathrm{PFV}=\mathrm{A} .1 \mathrm{SG} \text { buy-CMPL[в.3] three-CL.IN DEF book-PL=D2 } \\
& \text { 'I bought three of the books.' }
\end{aligned}
$$

Although quantifiers cannot be separated from their nP-complements, as seen in (23a, c), it is possible to separate quantifiers from partitive DPs; see (59). 


Jay-p'éel ts'o'ok a man-ik le áanalte'-o'ob=o'?
how.many-CL.IN TERM A.2 buy-INCMPL[B.3] DEF book-PL=D2
'How many of those books have you bought?'

These facts show that extraction is not limited to possessors, i.e. it does not depend on head-marking (as argued for cross-linguistic facts on possessor extraction by Gavruseva 2000).

We have seen that the heads of the extended projection of the noun cannot move leftwards - Yucatec Mayan does not allow Left Branch Extraction; see Section 3.2, in particular the ungrammaticality of the examples in (23). Recall that the same elements cannot be extraposed to the right; see (53). Consequently, the well-formed discontinuity in (59) cannot merely involve the movement of a head to the preverbal focus position. Rather, what appears there must be a complete maximal projection. For this to be possible, jay-p'éel must have undergone remnant movement. First, le áanalte' $o$ 'ob $=o$ ' was moved out of the quantified DP in a process of extraposition to the right, which is responsible for the separation of the quantifier and the partitive DP. Then, the remnant DP [jay-p'éel $t$ ] containing the trace of the partitive moves to the preverbal focus position, yielding (59). Recall that Spec,FP allows reconstruction of binding, so that the trace of the partitive DP is still properly bound when carried along to the focus position. ${ }^{16}$

In general, PP adjunction within DPs is not productive in Mayan languages. The corresponding native construction is a possessive phrase. Native speakers accept embedded PPs, but we should take such data with caution, since this construction might have been borrowed from Spanish. To the extent that the possibility of extraction is judged with reference to Yucatec Mayan syntax, this data reveal the structural possibilities in this language. Embedded PPs can be adjoined to the right of the head N, see (60).

(60) Ts'o'ok u jóok'-ol jun-p'éel áanalte' yo'osal ch'íich'-o'ob. TERM A.3 exit-INCMPL one-CL.IN book for bird-PL 'A book about birds has appeared.'

Discontinuous options with either the head nominal or the embedded PP in the prepredicate position are possible. Hence, PP adjuncts have the same possibilities as possessor DPs: it is possible to extract the PP or the nominal head to the Spec,FP; see $(61 \mathrm{a}, \mathrm{b})$.
(a)
Yo'osal ba'ax ts'o'ok a
a man-ik jun-p'éel
áanalte'? for what TERM A.2 buy-INCMPL[B.3] one-CL.IN book 'About what have you bought a book?' 17

[16] In principle, it should also be possible to move the partitive DP to the pre-predicate position, but that option seems excluded by independent constraints: definite DPs are not possible in the focus position, see Verhoeven \& Skopeteas 2015 for further details).

[17] The speaker was instructed to interpret the 'for'-phrase as related to the contents of the 'book'. 
(b) A: \{How many books about birds are appearing?\}

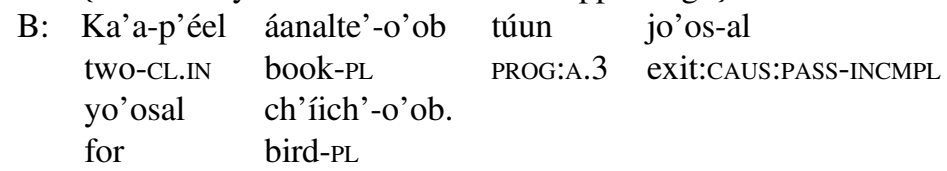

'TWO BOOKS about birds are appearing.'

Fronting the nominal head in (61b) is again an instance of remnant movement, which is supported by the possibility of PP extraposition, as in (62).

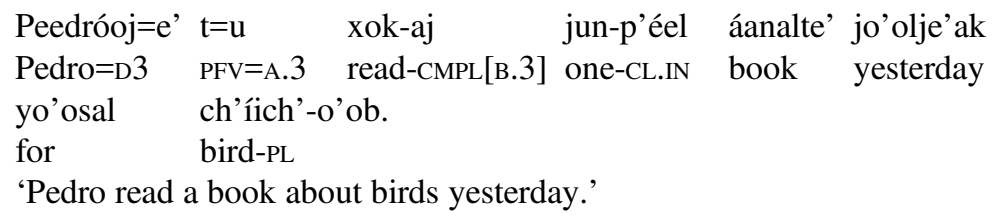

This section presented evidence that several classes of maximal projections (possessors, partitives, adjunct PPs) can be subextracted from the nominal structure in Yucatec Maya. These categories have in common that they can be right extraposed within the clause proper - in contrast to specifiers of the left branch. These facts show that a derivational scenario that starts with the right extraposition of a subconstituent of the nominal projection is compatible with the categories that may appear in the Spec,FP. Furthermore, these facts strengthen the conclusions of Section 4, that the presence of a locative anaphor indicates that subextraction of nominal heads is mediated by a derivational step in which the remnant is a complete nominal projection.

\section{Concluding Remarks}

The survey of the discontinuous noun phrases of Yucatec Maya revealed three properties that will be discussed in the following. First, Yucatec Maya displays two types of discontinuous structures: split topicalization does not involve evidence for $\overline{\mathrm{A}}$-movement and allows for several mismatches between the construction's parts that do not occur in continuous nominal projections. Constructions with nominal heads, possessors and further XPs in the focus position do not allow for such mismatches and show evidence for $\bar{A}$-movement. Second, while split topicalization is unrestricted, subextraction is only possible for nominal heads and possessors, but not from the left branch of the DP. Third, in instances of split topicalization, native speakers generally preferred examples with the remnant in the focus position in contrast to examples with a remnant in the clause proper.

Split topicalization differs from proper instances of subextraction in several respects, as summarized in Table 1. Split topicalization allows for mismatches that are excluded with continuous noun phrases or with proper instances of subextraction; compare (30)-(32) with (38)-(39). Furthermore, while proper instances of 


\begin{tabular}{lcc}
\hline Properties & Split topicalization & Subextraction \\
Mismatches & $\checkmark$ & - \\
Condition on Extraction Domain & - & $\checkmark$ \\
Reconstruction for binding & - & $\checkmark$ \\
\hline
\end{tabular}

Table 1

Differences between split topicalization and subextraction to the Spec,FP.

subextraction are subject to conditions on the extraction domain, as shown with the difference between arguments in (43) and adjuncts in (44), split topicalization is unrestricted, as shown by the insensitivity to islands of extraction in (28) for modifiers and in (45) for possessors. Finally, possessors in the focus position but not in the topic position reconstruct for binding; see (56) and (57), Section 5.4.

These differences are fully in line with the properties of the left-peripheral configurations that have been independently established in the research on Yucatec Mayan syntax. While topics are first merged at the CP layer, foci are $\overline{\mathrm{A}}$-moved and therefore related to a trace in the thematic layer of the clause. This generalization straightforwardly accounts for the properties of discontinuous constructions. In the topic construction, one of the two projections is generated outside the FP. Material outside FP is, apparently, syntactically invisible, so there is no reason why the two DPs should harmonize with respect to determiners and agreement, conditions on extraction do not apply and reconstruction effects do not arise. These constructions have the same properties as cases of nP/DP ellipsis; see (25) and (26) above. Hence, the elided nominal subconstituent is not recovered by binding, but by pragmatic mechanisms of identifying the maximally relevant antecedent in the context.

$$
\begin{aligned}
& \text { Left adjunction of topics } \\
& \text { Possessor-topics: [CP DP [CP op [ }{ }_{\mathrm{FP}} \ldots .{ }_{\mathrm{nP}} \mathrm{N} e \text { ] ...]]] } \\
& \text { nP-topics: } \quad[\mathrm{CP} \mathrm{nP}[\mathrm{CP} \text { op }[\mathrm{FP} \ldots[\mathrm{QP} \mathrm{Q} e \ldots]]]]
\end{aligned}
$$

The situation is different when both projections are part of the FP. In this case, we have a proper instance of subextraction, involving string-identity between the discontinuous and the corresponding continuous option, giving rise to reconstruction effects and showing sensitivity to the properties of the extraction domain. Furthermore, the predictions of a model postulating successive cyclic movement out of DP are not borne out in Yucatec Maya, especially since subextracted possessors do not appear with the morphological properties that are expected for possessors in Spec,DP; see Section 5.3. Finally, the facts from subextracted possessors, partitives and adjunct PPs show that the projections that allow for subextraction also allow for extraposition to the right; see Section 5.4. Thus, we conclude that the instances of subextraction in our data are mediated by a derivational step involving a complete $\mathrm{nP} / \mathrm{QP} / \mathrm{AP}$ in the clause proper. 
(64) $\bar{A}$-movement to the focus position (via extraposition to the right)

Possessor-foci: $\quad\left[\mathrm{FP}_{\mathrm{FP}} \mathrm{DP}_{\mathrm{i}}\left[\mathrm{F}^{\prime}\left[{ }_{\mathrm{TP}} \ldots\left[{ }_{\mathrm{nP}} \mathrm{n} t_{\mathrm{i}}\right] t_{\mathrm{i}}\right] \ldots\right]\right]$

nP-foci: $\quad\left[\mathrm{FP}_{\mathrm{FP}} \mathrm{nP}_{\mathrm{i}}\left[\mathrm{F}^{\prime}\left[\mathrm{TPP} \ldots\left[\mathrm{Q} / \mathrm{AP} \mathrm{Q} / \mathrm{A} t_{\mathrm{i}}\right] t_{\mathrm{i}}\right] \ldots\right]\right]$

Our findings from Yucatec Maya differ from languages in which split topicalization combines mismatches with evidence for $\bar{A}$-movement, in particular the German data reported in Fanselow (1988), Ott (2012), among many others. This difference follows from the different syntax of topicalization in these languages. Topics get to the left periphery of German CPs by Ā-movement, which does not hold in Yucatec Maya. Hence, the constructions of split topicalization in these languages do not share the same derivational history. Putting it differently, the construction of German that is derivationally equivalent to split topicalization in Yucatec Maya is not the construction with a subextracted PP in the prefield, as in (65a), but a construction expressing the same propositional content with a separate $\mathrm{CP}$ for the topic, as in (65b).

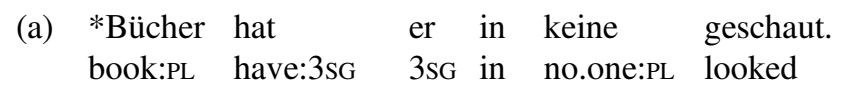

'He has not looked into any books.'

(b) Was Bücher angeht, hat er in

what book:PL concern:3sG have:3SG $3 \mathrm{sg}$ in

keine geschaut.

no.one:PL looked

'What books concerns, he has not looked into anyone.'

The latter construction contains an elliptical DP in situ and shares the insensitivity to conditions on the extraction domain with the Yucatec Maya facts in (28).

A second major finding in our data is that subextraction is only possible for nominal heads and possessors, but not from the left branch of the nominal projection. Yucatec Maya differs from further Mayan languages in this respect, which also allow for possessor extraction as described in Section 5 above; see Tsotsil in (66a) and Ch'ol in (66b).

\section{(a) Tsotsil}

Buch'u av-il-be s-tot?

who A.2-see-IO A.3-father

'Whose father did you see?'

(b) Ch'ol

Maxki tyi yajl-i i-plato?

who PFV fall-INTR A.3-plate

'Whose plate fell?' 
However, Tsotsil and Ch'ol allow Left Branch Extraction, which we found impossible in Yucatec Maya; see (67a, b) and detailed discussion in Aissen (1987: 253-261) and Bale et al. (2019) on Ch'ol.

(a)

Tsotsil
Pox-vo? $\quad$ Pi-s-mil-ik viniketik li jsoktometik=e.
three-CL.AN CMPL-A.3-kill-PL man:PL DEF Chiapaneco:PL=CLT
'The Chiapanecos killed three men.'

(Aissen 1987: 260)

(b) Ch'ol

Ux-tyikil ta' jul-i-y-ob $\quad$ 'ikik.
three-CL.HUM PFV arrive-PL
'I bought three oranges.'

(Bale et al. 2019: 19)

The nominal structure of these languages is prima facie very similar: bare referential noun phrases are possible, while definite and indefinite determiners occur frequently (see e.g. Tsotsil in Aissen 1987: 3-5; Ch'ol in Coon 2010: 207-211). The constraint on Left Branch Extraction in Yucatec Maya indicates that nominal projections of this language are a step further in the emergence of DP structure. Definiteness is a recent development; the erstwhile demonstrative is used as a definite article in the contemporary language (see discussion and references in Section 3.1).

Finally, in split topicalization native speakers had a general preference for the examples with the remnant in the focus position (compared to examples with a remnant in the clause proper). This preference is in line with our understanding of the factors that underlie discontinuity: the optimal contextual conditions for discontinuous noun phrases are expected to license feature-checking operations that lead subconstituents of the same nominal to different functional projections (hosting topics and foci) (see Fanselow \& Ćavar 2002). The question is why this preference does not apply to all languages: in contrast to Yucatec Maya, the remnant quantifier in split topicalization remains in situ in several languages; see Bulgarian (Giusti \& Dimitrova-Vulchanova 1996: 134) or Italian (Longobardi 1991).

A language showing the same patterns we found for Yucatec Maya is Hungarian, a language with a very similar 'discourse configurational' organization, with a leftperipheral topic projection and an immediately preverbal focus projection (compare Hungarian in É. Kiss 1998 and Mayan in Aissen 1992). Crucially, the quantifier should be in the focus position in Hungarian, just as in Yucatec Maya, while the alternative option with a quantifier in situ is suboptimal. Hungarian nominal structures are DPs (É. Kiss 2004: 151-157) which do not allow for Left Branch Extraction, as seen in (68a), which tests extraction of the quantifier in the topic position (particle-verb order) and the focus position (verb-particle order). Split topicalization appears as in (68b), in which case the quantifier in the focus slot is an elliptical DP and bears accusative case, which is not possible in continuous DPs; compare (68c) (see Szabolcsi 1994: Section 2). 
(68)

Hungarian

(a) *Hárm(-at) meg-vett / vett meg Mari szék-et. three-ACC PFV-buy.3sG.PST buy.3sG.PST PFV Mary[NOM] chair-ACC Intended: 'Mary bought three chairs.'

(b) Szék-et hárm-at vett meg/*meg-vett Mari. chair-ACC three-ACC buy.3sg.PST PFV/PFv-buy.3sG.PST Mary[NOM] 'Mary bought three chairs.'

(c) Három(*-at) szék-et meg-vett Mari. three-ACC chair-ACC PFV-buy.PST.3sg Mary[NOM] 'Mary bought three chairs.'

(Gábor Müller, Kriszta Szendrői, p.c.)

A crucial property that Hungarian and Yucatec Maya have in common is that narrow focus can only be expressed ex situ (see É. Kiss 1998 on Hungarian, Verhoeven \& Skopeteas 2015 on Yucatec Maya). This property may account for the fact that both subconstituents of split topicalization preferably appear in distinct left-peripheral positions. A salient difference of Yucatec Maya within the language family is that it is one of the few Mayan languages (along with Uspantek) displaying lexical tones, which substantially restricts the use of tonal events to spell out discourse features. Kügler \& Skopeteas (2007) report that there is no evidence for prosodic reflexes of focus on the realization of lexical tones. ${ }^{18}$ This suggests that the array of constructions that allow for the realization of discourse features such as topic and focus interacts with the grammar of discontinuous noun phrases, as one should expect, given the fact that these constructions appear when noun phrase subconstituents come with distinct discourse features. Hence, cross-linguistic differences in prosody, in particular the possibility to express focus in situ by prosodic means, may account for aspects of cross-linguistic variation that cannot be traced back to differences in the core syntax.

Let us conclude by putting our results into a broader crosslinguistic perspective. Yucatec Maya differs sharply from the North American languages that productively use the extraction of attributive modifiers (demonstratives, quantifiers and adjectives) to left-peripheral positions for topics and foci; see e.g. Swampy Cree in Reinholtz (1999), Maliseet-Passamaquoddy in LeSourd (2004) and several Algonquian languages in Johnson \& Rosen (2015). Yucatec Maya shares with these languages a rich verbal morphology and null arguments, which have been hypothesized as concomitants of the non-configurationality of these languages on a par with the discontinuity of NPs (see pronominal argument hypothesis by Jelinek 1984), but it turns out that this language disallows Left Branch Extraction - not a surprising fact given the presence of overt determiners (see Bošković 2005).

[18] It is not clear whether this property is generalizable for the further Mayan languages. The available prosodic studies for Ch'ol and Tsotsil provide accounts for the phrasing of leftperipheral and postverbal constituents, but do not directly address the question whether these languages have a local means (e.g. a pitch accent) for signaling focus in situ (Aissen 1992, Clemens \& Coon 2018b). However, these languages are not strictly comparable with Yucatec Maya/Hungarian, since they allow for Left Branch Extraction. 
Yucatec Maya allows noun incorporation into the verb (Lehmann \& Verhoeven 2005), but not of the Classifier type introduced by Rosen (1989), i.e. there can be no modifier numeral or quantifier in the object position linked to the incorporated noun (Gutiérrez Bravo 2002: 146). Putting it differently, no 'noun phrase discontinuity' can arise in Yucatec Maya in the context of incorporation (Gutiérrez Bravo 2002: 146). In this respect, Yucatec Maya resembles Chukchee, which has discontinuous noun phrases and allows noun incorporation, but only of the Compound type (Spencer 1995). In contrast, there is a Classifier type (Rosen 1989) of noun incorporation in many polysynthetic languages such as Mohawk, in which an incorporated noun can be modified by an adjective or a numeral in object position, so that a constellation quite similar to discontinuous noun phrases arises. This type of polysynthetic language lacks discontinuous noun phrases according to Baker (1996).

\section{APPENDIX}

\section{Yucatec Maya texts}

Academia de la Lengua y Cultura Mayas de Quintana Roo. 2007. U tsikbalilo'ob u ba'alche'ilo'ob u k'áaxil Sian Ka'an [Animal stories of the jungle of Sian Ka'an]. Felipe Carrillo Puerto: Ma'alobil ti' tu láakal máak.

Can Canul, César \& Rodrigo Gutiérrez Bravo. 2016. Maayáaj tsikbalilo'ob Kaampech, Narraciones mayas de Campeche [Mayan stories from Campeche]. Mexico City: Instituto Nacional de Lenguas Indígenas.

Collí Collí, Amedée, Fray Martín Collí Collí, Juan Cimá Barzón, Carlos Gracida Juárez \& A.C.U' Yo'olChé. 2007. U tsikbal tuusilo'ob yéetel u na'atilo'ob u k'áaxil $u$ lu'um maayáao'ob [Stories and riddles from the Mayan jungle]. Chichimila, Yucatán: Mayáon.

Edmonson, Munro S. 1982. The ancient future of the Itza: The book of Chilam Balam of Tizimin. Austin, TX: University of Texas Press.

Lehmann, Christian. 1989-2019. Yucatec Mayan text collection. https:/www. christianlehmann.eu/ling/sprachen/maya/textos/ (accessed 30 May 2020).

Monforte, Jorge, Lázaro Dzul \& Rodrigo Gutiérrez Bravo. 2010. Narraciones mayas [Mayan stories]. México, DF: INAL.

\section{REFERENCES}

Abney, Steven Paul. 1987. The English noun phrase in its sentential aspect. Ph.D. dissertation, MIT. Aissen, Judith. 1987. Tzotzil clause structure. Dordrecht: Reidel.

Aissen, Judith. 1992. Topic and focus in Mayan. Language 68, 43-80.

Aissen, Judith. 1996. Pied-piping, abstract agreement, and functional projections in Tzotzil. Natural Language \& Linguistic Theory 14, 447-491.

Aissen, Judith. 2017. Information structure in Mayan. In Aissen et al. (eds.), 293-324. 
Aissen, Judith. 2020. Documenting topic and focus. Ms., University of California, Santa Cruz. [To appear in Language Documentation and Conservation; available at https://people.ucsc.edu/ aissen/pubs.html, 21 October 2020.]

Aissen, Judith, Nora C. England \& Roberto Zavala Maldonado (eds.). 2017. The Mayan languages. New York: Routledge.

AnderBois, Scott. 2017. Focus, interrogation, and indefinites. In Aissen et al. (eds.), 348-361.

Armstrong, Grant. 2017. The syntax of non-verbal predication in Yucatec Maya. Cuadernos de Lingüística de El Colegio de México 4.2, 137-212.

Avelino, Heriberto, Jessica Coon \& Elisabeth Norcliffe (eds.). 2009. New perspectives in Mayan linguistics (MIT Working Papers in Linguistics 59). Cambridge, MA: MIT Working Papers in Linguistics.

Baker, Mark C. 1996. The polysynthesis parameter. Oxford: Oxford University Press.

Baker, Mark C. 2001. The natures of nonconfigurationality. In Mark Baltin \& Chris Collins (eds.), The handbook of contemporary syntactic theory, 407-438. Oxford: Blackwell.

Bale, Alan, Jessica Coon \& Nicolás Arcos López. 2019. Classifiers, partitions, and measurements: Exploring the syntax and semantics of sortal classifiers. Glossa: A Journal of General Linguistics 4.1, $1-30$.

Bickel, Balthasar, Walter Bisang \& Yogendra P. Yādava. 1999. Face vs. empathy: The social foundations of Maithili verb agreement. Linguistics 37, 481-518.

Bohnemeyer, Jürgen. 1998. Time relations in discourse: Evidence from a comparative approach to Yukatek Maya. Ph.D. dissertation, Katholieke Universiteit Brabant.

Bohnemeyer, Jürgen. 2009. Linking without grammatical relations in Yucatec: Alignment, extraction, and control. In Johannes Helmbrecht, Yoko Nishina, Yong-Min Shin, Stavros Skopeteas \& Elisabeth Verhoeven (eds.), Form and function in language research, 185-214. Berlin: Mouton de Gruyter.

Bošković, Željko. 2005. On the locality of Left Branch Extraction and the structure of NP. Studia Linguistica 59.1, 1-45.

Bricker, Victoria R. 1979. Wh-questions, relativization, and clefting in Yucatec Maya. In Laura Martin (ed.), Papers in Mayan inguistics, 107-136. Columbia, MO: Lucas Brothers.

Broadwell, George Aaron. 2005. Pied-piping and optimal order in K'iche'. Ms., University at Albany, State University of New York.

Brown, Linda Kay. 1979. Word formation in Pocomchi (Mayan). Ph.D. dissertation, Stanford University.

Butler, Lindsay Kay. 2012. Cross-linguistic and experimental evidence for non-number plurals. Linguistic Variation 12.1, 27-56.

Cinque, Guglielmo. 1994. Evidence for partial N-movement in the Romance DP. In Guglielmo Cinque, Jan Koster, Jean-Yves Pollock, Luigi Rizzi \& Rita Zanuttini (eds.), Paths towards Universal Grammar: Studies in honor of Richard Kayne, 85-110. Washington, DC: Georgetown University Press.

Clemens, Lauren \& Jessica Coon. 2018a. Deriving verb-initial word order in Mayan. Language 94.2, 237-280.

Clemens, Lauren \& Jessica Coon. 2018b. Prosodic constituency of verb-initial clauses in Ch'ol. In Megan Keogh (ed.), Proceedings of the The 21st Workshop on Structure and Constituency in Languages of the Americas (WSCLA 2016), 88-100. Vancouver, BC: University of British Columbia Press.

Comrie, Bernard, Martin Haspelmath \& Balthasar Bickel. 2015. Leipzig Glossing Rules: Conventions for interlinear morpheme-by-morpheme glossing. Leipzig: Max Planck Institute for Evolutionary Anthropology.

Coon, Jessica. 2008. When ergative = genitive: Nominals and split ergativity. In Natasha Abner \& Jason Bishop (eds.), Proceedings of the 27th West Coast Conference on Formal Linguistics (WCCFL 27), 99-107. Somerville MA: Cascadilla Proceedings Project.

Coon, Jessica. 2009. Interrogative possessors and the problem of pied-piping in Chol. Linguistic Inquiry $40.1,165-175$.

Coon, Jessica. 2010. Complementation in Chol (Mayan): A theory of split ergativity. Ph.D. dissertation, MIT.

Coon, Jessica. 2016. Mayan morphosyntax. Language and Linguistic Compass 10.10, 515-550.

Coon, Jessica. 2018. Distinguishing adjectives from relative clauses in Chuj (with help from Ch'ol). In Laura Kalin, Jozina van der Klok \& Ileana Paul (eds.), Heading in the right direction: Linguistic treats 
for Lisa Travis (McGill Working Papers in Linguistics 25.1), 90-99. Montreal: McGill University, Linguistics Department.

Coon, Jessica, Pedro Mateo Pedro \& Omer Preminger. 2014. The role of case in A-bar extraction asymmetries: Evidence from Mayan. Linguistic Variation 14, 179-242.

Dayley, Jon P. 1985. Tzutujil grammar. Berkeley, CA: University of California Press.

É. Kiss, Katalin. 1998. Identificational focus versus information focus. Language 74, 245-273.

É. Kiss, Katalin. 2004. The syntax of Hungarian. Cambridge: Cambridge University Press.

England, Nora C. 1983. A grammar of Mam, a Mayan language. Austin, TX: University of Texas Press.

England, Nora C. 2004. Adjectives in Mam. In R. M. W. Dixon \& Alexandra Y. Aikhenvald (eds.), Adjective classes: A cross-linguistic typology, 125-146. Oxford: Oxford University Press.

Fanselow, Gisbert. 1988. Aufspaltung von NPn und das Problem der "freien" Wortstellung [Splitting NPs and the problem of 'free' word order]. Linguistische Berichte 114, 91-113.

Fanselow, Gisbert. 2013. Morphological mismatches in discontinuous noun phrases. In Holden Härtl (ed.), Interfaces of morphology: A Festschrift for Susan Olsen, 11-25. Berlin: De Gruyter.

Fanselow, Gisbert \& Damir Ćavar. 2002. Distributed deletion. In Artemis Alexiadou (ed.), Theoretical approaches to universals, 64-109. Amsterdam: John Benjamins.

Féry, Caroline, Alla Paslawska \& Gisbert Fanselow. 2007. Discontinuous constructions in Ukrainian. Journal of Slavic Linguistics 15.1, 3-48.

Gavruseva, Elena. 2000. On the syntax of possessor extraction. Lingua 110, 743-772.

Giusti, Giuliana \& Mila Dimitrova-Vulchanova. 1996. Quantified noun phrase structure in Bulgarian. Formal Approaches to Slavic Linguistics 3, 123-144.

Grinevald Craig, Colette. 1977. Jacaltec: The structure of Jacaltec. Austin, TX: University of Texas Press.

Gutiérrez Bravo, Rodrigo. 2002. Formas verbales incorporadas transitivas en maya yucateco [Transitive incorporated verb forms in Yucatec Maya]. In Paulette Levy (ed.), Del cora al maya yucateco: estudios lingüísticos sobre algunas lenguas indígenas mexicanas [From Cora to Yucatec Maya: Linguistic studies on some indigenous Mexican languages], 131-178. Mexico: UNAM.

Gutiérrez Bravo, Rodrigo. 2011. External and internal topics in Yucatec Maya. In Rodrigo Gutiérrez Bravo, Line Mikkelsen \& Eric Potsdam (eds.), Representing language: Linguistic essays in honour of Judith Aissen, 105-119. Lexington, KY: Linguistics Research Center.

Gutiérrez Bravo, Rodrigo. 2015. Las cláusulas relativas en maya yucateco [Relative clauses in Yucatec Maya]. México, D.F: El Colegio de México.

Gutiérrez Bravo, Rodrigo. 2017. Cleft and focus in Yucatec Maya. Cuadernos de Lingüística de El Colegio de México 4, 5-47.

Gutiérrez-Bravo, Rodrigo \& Jorge Monforte y Madera. 2008. La alternancia sujeto inicial/verbo inicial y la teoría de la optimidad [The subject-initial/verb-initial alternation and Optimality Theory]. In Rodrigo Gutiérrez Bravo \& Esther Herrera Zendejas (eds.), Teoría de la optimidad: estudios de sintaxis y fonología [Optimality Theory: Studies on syntax and phonology], 61-90. Mexico D.F.: El Colegio de México.

Gutiérrez Bravo, Rodrigo \& Jorge Monforte y Madera. 2010. On the nature of word order in Yucatec Maya. In José Camacho, Rodrigo Gutiérrez Bravo \& Liliana Sánchez (eds.), Information structure in indigenous languages of the Americas, 139-170. Berlin: Mouton de Gruyter.

Haider, Hubert \& Luka Szucsich. 2020. Scrambling and V-positioning in Slavic languages: Exceptionally VO or regular T3? Ms., University of Salzburg \& Humboldt-Universität zu Berlin. [Forthcoming in Roland Hinterhölzl, Kristine Bentzen, Augustin Speyer \& Luka Szucsich (eds.), The German middle field in a comparative and diachronic perspective. Berlin: Mouton de Gruyter. Available at https://www.semanticscholar.org/paper/Scrambling-and-V-positioning-in-Slavic-languages-VOHaider-Szucsich/bda02d8ddedf49294fbc36dcf2b07349ed792dbb, 21 October 2020.]

Hale, Ken. 1983. Warlpiri and the grammar of non-configurational languages. Natural Language \& Linguistic Theory 1, 5-47.

Heck, Fabian. 2009. On certain properties of pied-piping. Language 40.1, 75-111.

Henderson, Robert. 2012. Morphological alternations at the Intonational Phrase edge: The case of K'ichee'. Natural Language \& Linguistic Theory 30.3, 741-787.

Hofling, Charles Andrew. 1991. Itzá Maya texts: With a grammatical overview. Salt Lake City, UT: University of Utah Press.

Hofling, Charles Andrew. 2000. Itzáj Maya grammar (with Félix Fernando Tesucún). Salt Lake City, UT: University of Utah Press. 


\section{DISCONTINUOUS NOUN PHRASES IN YUCATEC MAYA}

Hornstein, Norbert, Jairo Nunes \& Kleanthes K. Grohmann. 2005. Understanding Minimalism. Cambridge: Cambridge University Press.

Horrocks, Geoffrey \& Melita Stavrou. 1987. Bounding theory and Greek syntax: Evidence for whmovement in NP. Journal of Linguistics 23, 79-108.

Huang, Cheng-Teh James. 1982. Logical relations in Chinese and the theory of grammar. Ph.D. dissertation, MIT.

Janke, Vikki \& Ad Neeleman. 2012. Ascending and descending VPs in English. Linguistic Inquiry 43.2, 151-190.

Jelinek, Eloise. 1984. Empty categories, case, and configurationality. Natural Language \& Linguistic Theory 2, 39-76.

Jeoung, Helen. 2016. Possessor extraction in Indonesian type languages. Proceedings of the Linguistic Society of America 1, 1-35.

Johnson, Meredith \& Bryan Rosen. 2015. The syntax of discontinuous phrases in Algonquian languages: Left Branch Extraction and focus movement. Papers of the 43rd Algonquian Conference, 135-150. Albany, NY: SUNY Press.

Krifka, Manfred. 2008. Basic notions of information structure. Acta Linguistica Hungarica 55.3-4, 243-278.

Kügler, Frank \& Stavros Skopeteas. 2007. On the universality of prosodic reflexes of contrast: The case of Yucatec Maya. 16th International Congress of Phonetic Sciences, 6-10 August 2007, Saarbrücken, Germany (ICPhS XVI), 1025-1028.

Lehmann, Christian. 1990. Yukatekisch [Yucatec]. Zeitschrift für Sprachwissenschaft 9.1-2, $28-51$.

Lehmann, Christian. 2002. Possession in Yucatec Maya, 2nd edn. Erfurt: Seminar für Sprachwissenschaft der Universität.

Lehmann, Christian \& Elisabeth Verhoeven. 2005. Noun incorporation and participation: A typological study on participant association with particular reference to Yucatec Maya. In Christian Lehmann (ed.), Typological studies in participation, 105-188. Berlin: Akademie.

LeSourd, Philip. 2004. The internal structure of the noun phrase in Maliseet-Passamaquoddy. In H. Christoph Wolfart (ed.), Papers of the 35th Algonquian Conference, 239-263. Winnipeg, MB: University of Manitoba.

Little, Carol-Rose. 2020. Left Branch Extraction, object shift, and freezing effects in Tumbalá Ch'ol. Glossa: A Journal of General Linguistics 5.1, 1-29.

Longobardi, Giuseppe. 1991. Extraction from NP and the proper notion of head government. In Alessandra Giorgi \& Giuseppe Longobardi (eds.), The syntax of noun phrases, 57-112. Cambridge: Cambridge University Press.

Matthewson, Lisa. 2004. On the methodology of semantic fieldwork. International Journal of American Linguistics 70.4, 369-415.

Müller, Gereon. 1998. Incomplete category fronting: A derivational approach to remnant movement in German. Dordrecht: Kluwer.

Norcliffe, Elisabeth. 2009a. Head marking in usage and grammar: A study of variation and change in Yucatec Maya. Ph.D. dissertation, Stanford University.

Norcliffe, Elisabeth. 2009b. Revisiting agent focus in Yucatec. In Avelino et al. (eds.), 135-155.

Norman, William M. \& Lyle Campbell. 1978. Toward a proto-Mayan syntax: A comparative perspective on grammar. In Nora C. England (ed.), Papers in Mayan linguistics, vol. 2, 136-155. Columbia, MO: University of Missouri.

Ott, Denis Christopher. 2012. Local instability: Split topicalization and quantifier float in German. Berlin \& New York: de Gruyter.

Polian, Gilles. 2013. Gramática del tseltal de Oxchuc [A grammar of Oxchuc Tseltal]. Mexico D.F.: Centro de Investigaciones y Estudios Superiores en Antropología Social.

Reinholtz, Charlotte. 1999. On the characterization of discontinuous constituents: Evidence from Swampy Cree. International Journal of American Linguistics 65.2, 201-227.

Riemsdijk, Henk van. 1989. Movement and regeneration. In Paola Beninca (ed.), Dialectal variation and the theory of grammar, 105-136. Dordrecht: Foris.

Rosen, Sara Thomas. 1989. Two types of noun incorporation: A lexical analysis. Language 65.2, 294-317.

Ross, John Robert. 1986. Infinite Syntax! Norwood, NJ: Ablex.

Saez, Luis Á. 1991. Quantitative clitics in Romance and Slavic. Annuario del Seminario de Filología Vasca "Julio de Urquijo" (ASJU) 25.3, 713-735.

Shklovsky, Kirill. 2012. Person-case effects in Tseltal. The Linguistic Review 29.3, 439-490. 
Skopeteas, Stavros. 2010. Syntax-phonology interface and clitic placement in Mayan languages. In Vincenç Torrens, Linda Escobar, Anna Gavarró \& Juncal Gutiérrez (eds.), Movement and clitics, 307-331. Newcastle: Cambridge Scholars Publishing.

Skopeteas, Stavros \& Elisabeth Verhoeven. 2005. Postverbal argument order in Yucatec Maya. Sprachtypologie und Universalienforschung 53.1, 71-79.

Skopeteas, Stavros \& Elisabeth Verhoeven. 2009a. Distinctness effects on VOS order: Evidence from Yucatec Maya. In Avelino et al. (eds.), 157-173.

Skopeteas, Stavros \& Elisabeth Verhoeven. 2009b. The interaction between topicalization and structural constraints: Evidence from Yucatec Maya. Linguistic Review 26, 239-259.

Smith Stark, Thomas C. 1988. "Pied piping" con Inversion en Preguntas Parciales ['Pied piping' with inversion in partial questions]. Ms., Colegio de Mexico.

Spencer, Andrew. 1995. Incorporation in Chukchi. Language 71.3, 439-489.

Stepanov, Arthur. 2007. The end of CED? Minimalism and extraction domains. Syntax 10.1, 80-126.

Stiebels, Barbara. 2006. Agent focus in Mayan languages. Natural Language \& Linguistic Theory 24, 501-570.

Stolz, Christel, Thomas Stolz \& Elisabeth Verhoeven. 2012. Maya yucateco de X-hazil Sur, Quintana Roo. México D.F.: El Colegio de México.

Stump, Gregory T. \& Ramawatar Yadav. 1988. Maithili verb agreement and the control agreement principle. Papers from the Annual Regional Meeting of the Chicago Linguistic Society 24.2 (CLS 24.2), 304-321. Chicago, IL: Chicago Linguistic Society.

Szabolcsi, Anna. 1994. The noun phrase. In Ferenc Kiefer \& Katalin É. Kiss (eds.), Syntax and semantics: The syntactic structure of Hungarian, 179-274. San Diego, CA; Academic Press.

Tonhauser, Judith. 2003a. F-constructions in Yucatec Maya. In Jan Anderssen, Paula MenéndezBenito \& Adam Werle (eds.), The Proceedings of SULA 2, 203-223. Amherst, MA: University of Massachusetts Amherst, GLSA.

Tonhauser, Judith. 2003b. On the syntax and semantics of content questions in Yucatec Maya. In Juan Castillo (ed.), Proceedings of the 6th Workshop on American Indian Languages (WAIL) (Santa Barbara Papers in Linguistics), 106-121.

Vapnarsky, Valentina. 2013. Is Yucatec Maya an omnipredicative language? Predication, the copula, and focus constructions. Language Typology and Universals 66.1, 40-86.

Vázquez-Rojas Maldonado, Violeta, Josefina García Fajardo, Rodrigo Gutiérrez-Bravo \& Julia Pozas Loyo. 2018. The definite article in Yucatec Maya: The case of le...o'. International Journal of American Linguistics 84.2, 207-242.

Verhoeven, Elisabeth. 2007. Experiential constructions in Yucatec Maya. Amsterdam: John Benjamins. Verhoeven, Elisabeth \& Stavros Skopeteas. 2015. Focus in Yucatec Maya. International Journal of American Linguistics 81.1, 1-40.

Authors' addresses: (Skopeteas)

Linguistics Department, Georg-August University of Göttingen,

Käte-Hamburger-Weg 3, 37073 Göttingen, Germany

stavros.skopeteas@uni-goettingen.de

(Verhoeven)

Institut für deutsche Sprache und Linguistik,

Humboldt University Berlin, Dorotheenstraße 24,

10117 Berlin, Germany

elisabethverhoeven@hu-berlin.de

(Fanselow)

Department Linguistik, University of Potsdam,

Karl-Liebknecht-Straße 24-25, 14476 Potsdam, Germany

gisbert.fanselow@gmail.com 